\section{Farmsteads in early medieval Germany - architecture and organisation}

\section{Las alquerías altomedievales en Alemania - arquitectura y organización}

\section{Rainer Schreg*}

Römisch-Germanisches Zentralmuseum. Mainz (Germany)

\begin{abstract}
In Germany early medieval rural settlements are known from a rising number of excavated sites. Rural architecture was a wooden architecture. Only churches were built in stone. A farmstead consisted of several buildings: the main house and several economic buildings as pit houses and storages. Before the 1980s, when large scale excavations became more and more common, there was little awareness of changes in rural settlement history. The formation of still existing villages was only late in the Middle Ages. However, even today it is difficult to understand the changes in rural architecture as there are distinct regional differences. Probably the $5^{\text {th }}$ century on the one hand and the period of village formation between the $10^{\text {th }}$ and $13^{\text {th }}$ centuries on the other hand were the most innovative periods. This article provides a short characteristic of buildings and settlement organisation. He gives an outline of research history and identifies some recent trends and future perspectives of research.
\end{abstract}

Key words: Rural settlements, medieval villages, architecture, pit houses, early middle ages, Germany.

\section{Resumen}

Tenemos conocimiento de los asentamientos rurales de la alta Edad Media en Alemania gracias a un número creciente de excavaciones arqueológicas. La arquitectura rural es una arquitectura de madera, reservándose la piedra para las iglesias. Las alquerías comprendían varias edificaciones: la casa principal y varias construcciones destinadas a fines económicos, como las viviendas semienterradas y almacenes. Antes de los años 80 del siglo pasado, cuando las excavaciones a gran escala se hicieron más habituales, se conocía poco sobre la evolución de la historia de los asentamientos rurales. Las aldeas que aún permanecen se formaron a finales de la Edad Media e incluso hoy resulta difícil entender los cambios que se produjeron en la arquitectura rural cuando existen diferencias regionales. Es probable que el periodo comprendido entre el siglo $\mathrm{V}$, por una parte, y los siglos x y XIII por otra fue la de mayor innovación. El presente artículo ofrece un resumen de las características edificativas y la organización de los asentamientos, con un repaso de la historia de la investigación, las tendencias actuales y las perspectivas para investigaciones posteriores.

Palabras clave: asentamientos rurales; aldeas medievales; arquitectura; viviendas semienterradas; alta Edad Media; Alemania.

\footnotetext{
*Schreg@rgzm.de
}

After the Napoleonic wars in the mid- $19^{\text {th }}$ century, when national consciousness arose in Germany, history became a place of remembrance and a source of national identity. History was established as an academic discipline, and the first archaeological excavations were carried out. However, as interest focused mainly on the heroic Middle Ages and political history, little attention was paid to rural settlements. Continuity from the ancient Germans to the national state of the $19^{\text {th }}$ century was beyond question. Furthermore, there was no rural history at all: «The peasant is eternal, the village is outside of global history (Der Bauer ist geschichtslos, das Dorf steht außerhalb der Weltgeschichte)» as Oswald Spengler said (Spengler 2007, 668). Therefore, scholars did not perceive major changes in rural history. They used early modern sources to reconstruct the situation in the early Middle Ages and understood the medieval period only as a predecessor to the authoritarian national state of the $19^{\text {th }}$ century. Research on rural architecture therefore was a domain of architectural folklore (Heyne 1899).

Regarding the medieval rural village, this gave rise to the idea that the village community had its roots in the Germanic landnam during the Migration period. Architecture as well as the layout of settlements was thought to be an expression of ethnic identity. Therefore, most scholars did not take major changes into account (e.g. Heyne 1899, 71f.; Paret 1937). This ahistorical idea took on ideological implications as Friedrich Engels and other socialist writers identified remains of the communist primal society in the early modern rural commune. On the other hand, national socialist agrarian politics used the traditional rural farm and village as an ideal. They tried to improve the status of single farmsteads («Reichserbhöfe») in Germany, but also used the traditional village as a model for German colonisation in the conquered territories in Eastern Europe during World War II (compare Schreg 2006a).

However, at that time archaeological data already existed to show that medieval rural history was much more complex. The first excavation of an early medieval rural settlement took place in 1913. During railway construction near Kanzach, close to the famous Neolithic and Bronze Age lake dwellings of the Federsee, Merovingian burials were found. Excavations by Gerhard Bersu uncovered traces of post holes and pit houses (N.N. 1914/16). Because this early excavation was never published in detail, it was only later, in the 1930s, when rescue excavations at Merdingen, Hochstetten (Garscha et al. 1948-50), Gladbach (Wagner et al. 1938) and Mühltal (Ohlenroth 1937) began to reveal information about rural architecture 


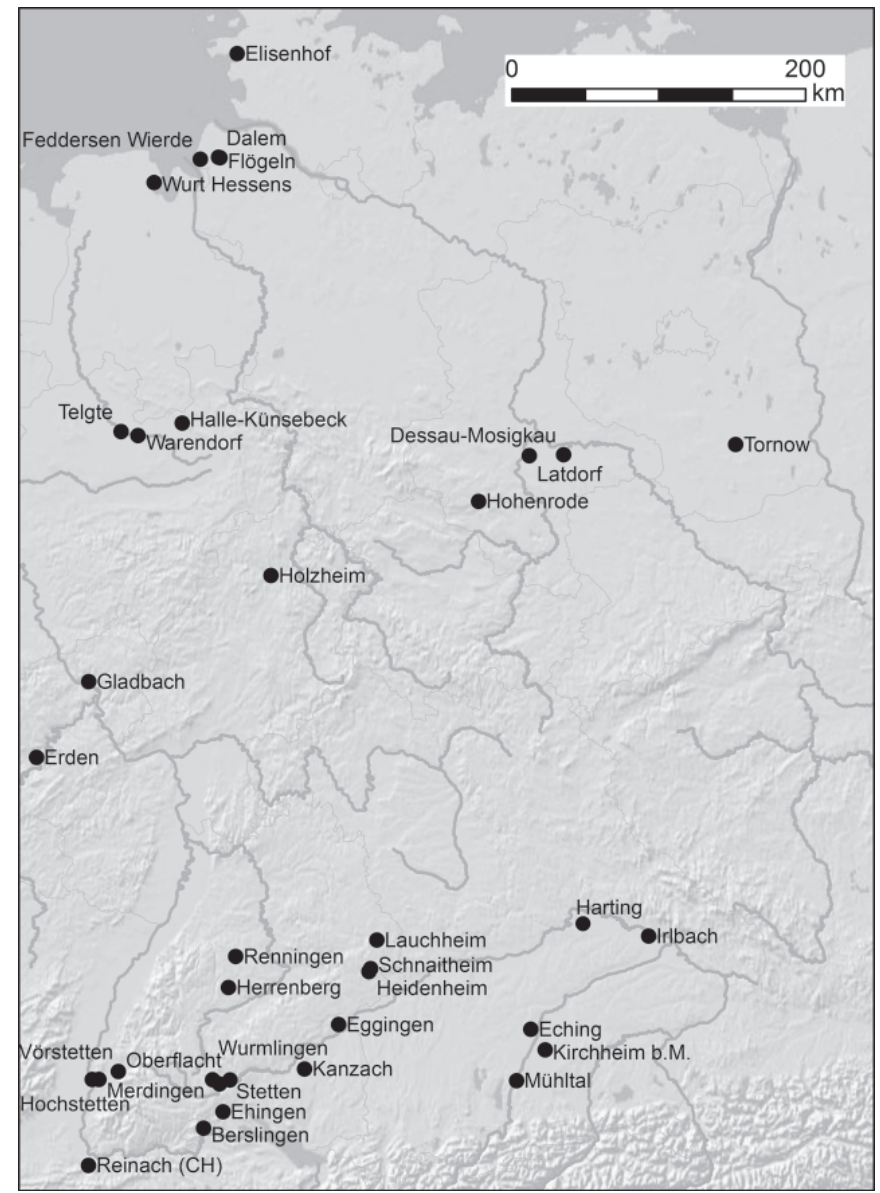

Fig. 1. Sites mentioned in the text (base map: ESRI)

(fig. 1). The first research excavation focused on a medieval rural settlement took place in 1935-1937 at the abandoned settlement of Hohenrode in the Southern Harz Mountains. This settlement had two periods of occupation - an early occupation with wooden architecture, dated to the $9^{\text {th }}$ to $12^{\text {th }}$ century, and a later one characterized by several buildings with stone foundation representing the late Middle Ages. Paul Grimm, who conducted this research, introduced many approaches that were highly innovative at that time. For example, he systematically used late medieval pictorial evidence to understand house construction and agrarian tools (Grimm 1939).

Until that time, medieval rural architecture had not been a focus of archaeological study. Studies were concerned with prehistoric houses (Schulz 1913), but medieval houses were seen as a topic for ethnographers and geographers using written documents and preserved «traditional» buildings (Dölling 1958; Phleps 1951; comp. Gebhard 1958). The model reconstruction of an early 'alamannic' house realized during the NS period by the Reichsbund für Deutsche Vorgeschichte (National Society for German prehistory) took a 17th century farmstead as a starting point (Schröder 1997). However, after WW II, archaeologists increasingly turned their interest to medieval settlements and soon they recognized that regional house types were influenced by geographical or economic factors rather than ethnographic characteristics (Behn 1957). Reconstructions by Wilhelm Winkelmann and Walter Sage based on the excavations at Warendorf and Gladbach (Winkelmann 1954; Sage 1965; Sage 1969) were the first to draw directly on archaeological evidence (fig. 2). They both showed a rather primitive architecture quite different from late medieval timber frame constructions and predominant roof constructions using rafters («Sparrendächer») (Bedal 1993). In both cases, the houses were built using post construction, and Winkelmann as well as Sage reconstructed a simple roof construction supported by purlins. In consequence, the changes from early medieval architecture to late medieval timber frame construction became an important topic of architectural research, which needed to consider archaeological as well as standing architectural evidence (Sage 1983; Bedal 1993; Bedal 1987; Zimmermann 1998). However, for quite a long time it was thought that there were no standing rural

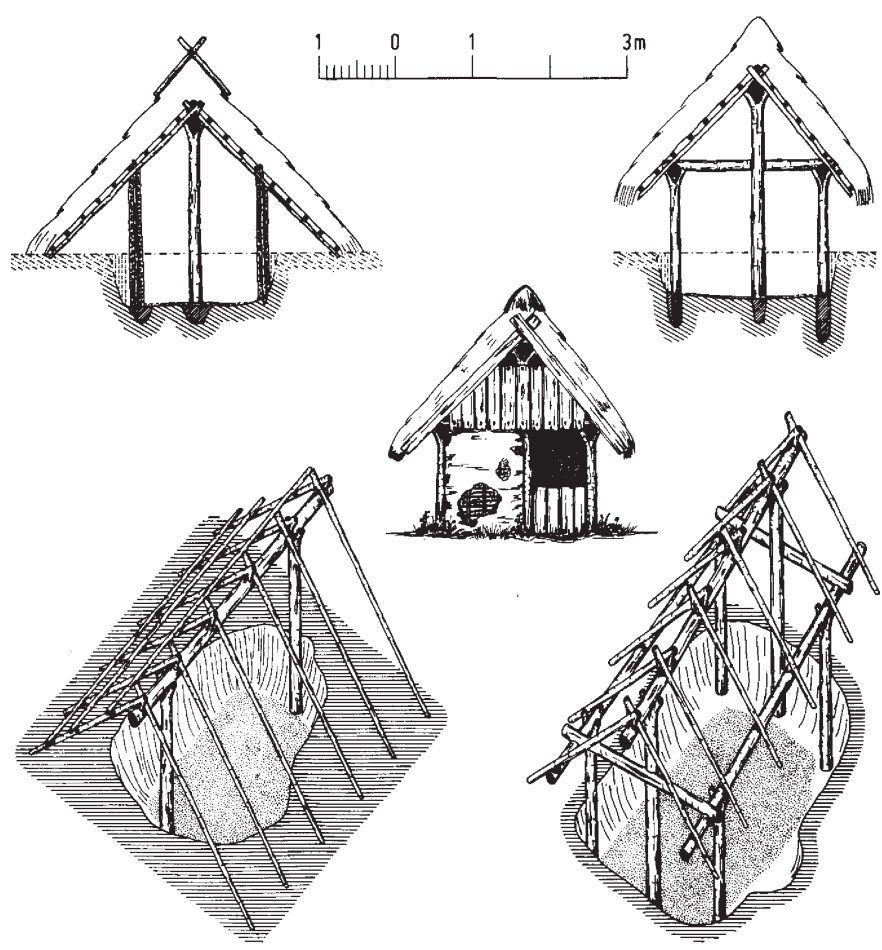

MWlW gewachsener Boden Grubenrandes Flechtwand künstlicher Hüttenboden(Sand) ---vermutliche alte Oberfläche

Fig. 2. Pit houses from Neuwied-Gladbach (Sage 1969) 
buildings from the time period before the $17^{\text {th }}$ century. Only in recent years modern architectural research, aided by dendrochronological dating, showed an impressive number of late medieval buildings.

Archaeological research on medieval settlements and rural architecture did not start with research questions, but was driven by the increasing need for rescue excavations. Two programmatic papers by Walter Janssen and Günther Fehring, both concentrating on later medieval periods, elaborated detailed research questions on rural settlements (Janssen 1968; Fehring 1973). They claimed the need for further archaeological investigations dealing with rural architecture. Many researchers still preferred to use the Merovingian cemeteries as well as place names as their main sources for an analysis of regional sttlement pattern (Dannheimer 1974).

The excavations of the Niedersächsisches Institut für Küstenforschung (Lower Saxony Institute for Coastal Research) at the North Sea coast were an important milestone in settlement archaeology. Starting with excavations at the Roman Iron Age and the Migration period settlement at the Wurt of Feddersen Wierde, 1953-1962 (Haarnagel 1979), several medieval settlements were investigated, as for example Wurt Hessens near Wilhelmshaven (Kossack et al. 1986; Siegmüller 2010). Excavations at Elisenhof and Flögeln provided the basis for a detailed analysis of rural architecture (Bantelmann 1975; Zimmermann 1992b; Zimmermann 1992a). This interest in rural settlements is part of a general turn of prehistoric archaeology towards settlement and landscape in the 1920s and early 1930s (e.g. Wahle 1920; Schumacher 1923; compare Gramsch 2003). "Siedlungsarchäologie», a term originally coined by Gustaf Kossinna to refer on archaeology of race and ethnic interpretation (Kossinna 1911), became an important concept in German archaeology after WWII mainly due to the work of Herbert Jankuhn (Jankuhn 1977). He characterised settlement archaeology concerned with problems of settlement pattern explicitely necglecting questions of ethic interpretation. As Jankuhn's interests included the early Middle Ages and the Viking period, settlement archaeology played an important role when medieval archaeology was established as a new field of research since the 1960s (Jankuhn 1973). In practice, however, medieval archaeology, deeply rooted in cultural heritage management, was mainly engaged in urban archaeology. The idea that early medieval settlements were hidden within the later villages was still widely accepted at that time, as well as the idea of a direct continuity of building traditions.
This kind of settlement archaeology was characteristic for research in Northern Germany. Excavations in two settlements near Flögeln shed light on early medieval rural architecture. Two settlements have been excavated, an earlier one at Flögeln «Eekhöltjen,» dating from the $1^{\text {st }}$ to the $6^{\text {th }}$ century (Zimmermann 1992b), and only 2 $\mathrm{km}$ away the later settlement of Dalem, dating from the $7^{\text {th }}$ to $14^{\text {th }}$ century (Zimmermann 1992a). Systematic phosphate analysis contributed to an understanding of house function. Quite important were the excavations within a $7^{\text {th }}-9^{\text {th }}$ c. settlement in Warendorf (Winkelmann 1954). More than 220 buildings of varying size were identified within an excavation area of about one hectare. A preliminary analysis by W. Winkelmann demonstrated the importance of excavations for understanding early medieval architecture. However, there was never a detailed publication of the Warendorf houses, and a comparable excavation in a nearby settlement at HalleKünsebeck in Westphalia came to attention only forty years later (Schroth 1999).

In the former German Democratic Republic, systematic archaeological investigations dealt with early medieval Slavonic settlements (Herrmann 1985; Biermann 2000), but with few exceptions, as for example Dessau-Mosigkau (Krüger 1967) or Tornow (Herrmann 1973), the focus was on fortified places. However, the Marxist perspective aroused some interest in rural economy and living further to the west as well. Peter Donat published a first synthesis on houses, farms and villages (Donat 1980), as well as many more ground breaking articles also after the German reunification (Donat 1977; Donat 1987; Donat 1991; Donat 2001).

In southern Germany, 'large' scale rescue excavations of early medieval settlements began only in the late 1970s and early 1980s. With the exception of excavations in the abandoned settlement of Holzheim near Fritzlar and at Speyer, which were funded by the German Research Foundation (DFG) (Bernhard 1982; Wand 2002), most activities were rescue excavations. Increasing land consumption and development lead to a rapidly increasing number of rescue excavations in medieval rural settlements. Especially in the area around Munich, many excavations were carried out (Winghart 1995; Schreg 2009), starting with Kirchheim bei München (Dannheimer 1973; Christlein 1980; Geisler 1993). At Kirchheim, an area of $2.500 \mathrm{~m}^{2}$ was excavated in 1970 , and one of $45.000 \mathrm{~m}^{2}$ in 1980 (fig. 3). For the first time, a nearly complete village plan was uncovered. Farmsteads were arranged along a central street. Near the street were small 


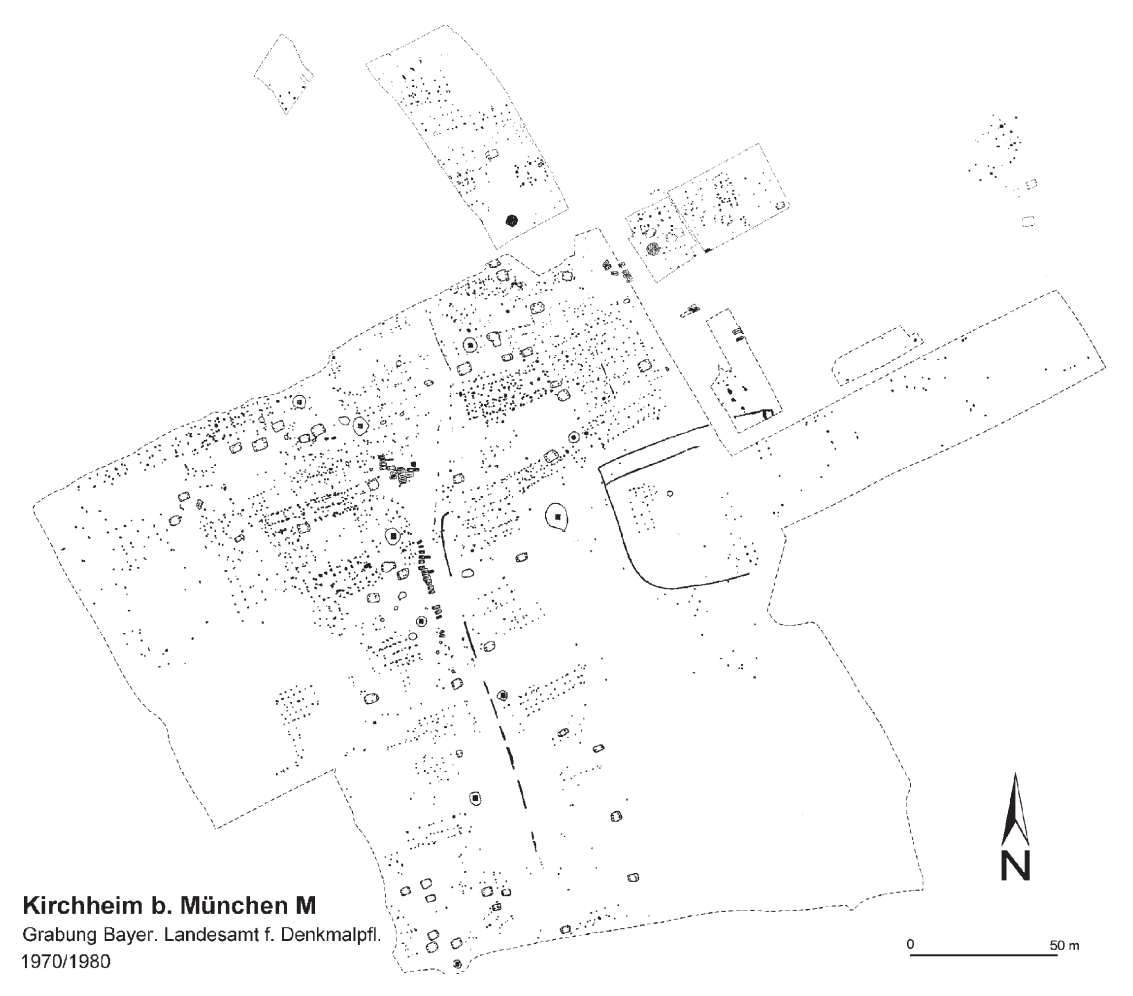

Fig. 3. Early medieval settlement and adjacent Iron Age farmstead (Schreg 2006b)

burial places, some with late Merovingian grave goods. The main houses were built as two-aisled wooden constructions. Details of walls and roofs were unknown, as in general the old floors were destroyed by later ploughing. Small fragments of burnt clay may represent clay infills or wattle and daub. Tiles are absent. In addition to the main houses there were some smaller buildings built of wooden posts as well as pit houses and wells.

Another important excavation within an early medieval settlement was in Lauchheim. Its situation is unique as it was possible to excavate the complete Merovingian cemetery as well as most parts of the adjacent settlement area. The settlement sprawled along the river Jagst, where a watermill channel has been identified. The analysis of the excavation is still in progress, and preliminary reports do not specify the number of farmsteads (Stork 2010). Little research has been done to investigate the settlement landscape surrounding the excavated site, which can be identified with a settlement called "Mittelhofen». Toponyms indicate that there were related settlement locations in the area around Lauchheim, which probably became a town in the $13^{\text {th }}$ century. As the toponym ending with «-heim» represents a late Merovingian period of place names, and names with «-hofen» are likely to be of a later origin, we may conclude that there was a kind of reorganisation or restructuring during the Middle Ages. The excavated settlement, however, started in the 6th century and continued in general up to the 12 th century. Another important source for information about early medieval settlement comes from research in the Renningen basin, also situated in southwest Germany. Excavations there were rather limited, but in addition to intensive fieldwalking and some small excavations, the State department of Cultural Heritage Management excavated representative parts of two settlements. The first, in an area called «Raite» belonged to the Migration period. In addition to some pit houses, there were also three-aisled houses. The other settlement («Neuwiesenäcker») revealed several houses, pit houses and two wells, dating mainly to the $10^{\text {th }}-12^{\text {th }}$ century (Schreg 2006b).

Since the 1990s there were many more important excavations, not only in Southern Germany and Northern Switzerland, but also in the Western part of the Rhineland, in the North and especially in the landscapes east of the river Elbe. Most of them have only been presented in very short preliminary publications. As medieval archaeology in most cases has very close ties to a distinct region, studies comparing different landscapes are rare (but see Brabandt 1993 for the Roman Iron Age; FriesKnoblach 2006). Furthermore, there are few publications aimed at an international research community (Dam- 


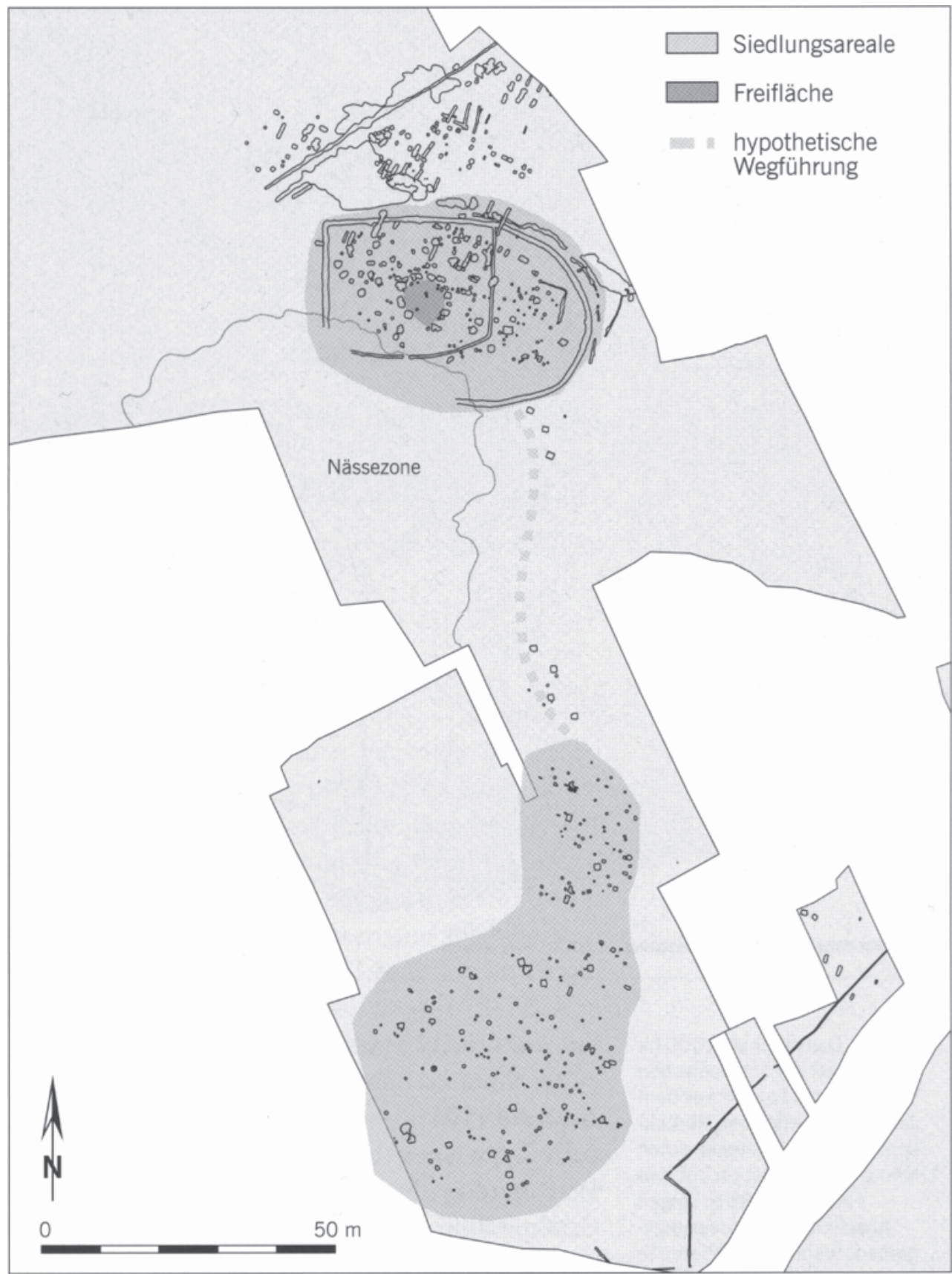

Fig. 4. Slavic 8th-10th c. settlements at Latdorf (Fahr et al. 2008)

minger 1998; Bücker, Hoeper 2000; contributions in Ruralia volumes).

\section{LANDSCAPES OF DIFFERENT ARCHITECTURAL TRADITIONS}

In order to deal with early medieval farmsteads we need to take different landscapes into account. There were not only different environmental conditions and economic orientations, but also different cultural traditions. Within the former Roman territories west of the Rhine and south of the Danube, there existed a settlement system of isolated farmsteads (villae rusticae) and a few villages, mainly related to the military, to transport, or to non-agrarian industries. Possibly these villages were of some importance for agrarian production, as they may have provided seasonal workers. Even in the agri decumates, the area protected by the Roman limes between the Rhine and the Danube in Southwest Germany, the settlement system of the migration period shows remarkably close ties to the Roman sites (Kuhnen 1992). In the $4^{\text {th }}$ and $5^{\text {th }}$ centuries, Roman stone 
architecture, or at least their ruins, were a starting point for settlement activities (e.g. Wurmlingen: Reuter 2003). For example, the Roman villa and vinery at Erden on the Mosel river near the Roman town of Trier was reorganized in the $5^{\text {th }}$ century. Several rooms were added to a stone building that formerly housed a vine press. The stone building was probably only used for a short time, but early medieval finds indicate that settlement activities continued in subsequent centuries (Gilles 1994).

The landscapes east of the river Elbe and some areas in central Germany represent another historical landscape, as they became part of the Germania Slavica with different cultural traditions and differing agricultural practices (Brather 2001). Excavations at Latdorf conducted in 2006/07 uncovered two contemporary adjacent settlements of the $8^{\text {th }}$ to $10^{\text {th }}$ century (fig. 4). The southern settlement consisted of 16 square pit houses in $\log$ construction. Their average size was $11.6 \mathrm{~m}^{2}$. In one corner, most often in the northwest, there was a small fireplace. Close to these houses were several storage pits. In the southern settlement the storage pits were in the centre of the settlement surrounded by the houses. The northern settlement had a different spatial organisation. Within a fortified area of around $0.6 \mathrm{ha}$, which was later enlarged, there were 8 pit houses circular arranged around a free space. In the later development of that settlement, the ditch system was enlarged and the pit houses regrouped to a rather irregular distribution (Fahr et al. 2008).

The region between the Rhine and the Elbe, which will be the focus of this article, also consists of several distinct landscapes. Written sources refer to different tribes such as the Frisians in the North, the Franks in the West, the Saxons and Thuringians in the east, and the Alamanns and Bavarians in the South. However, it is difficult to distinguish specific tribal architectural characteristics. In $4^{\text {th }} / 5^{\text {th }}$ c. Alamannia, we recognize influences of architectural traditions in Southwest Germany from quite different regions. Pithouses with a characteristic arrangement of posts reflect influences from the Elbe region and further to the east. This architectural influence accords well with the idea that the Alamannic tribe had its origins in those regions. Three-aisled main buildings however reflect traditions well known from Northern Germany (Schreg 2006b, 159ff; see below). Differing landscape conditions, land use practices and population densities were probably much more important for the settlement organisation and rural architecture than specific ethnic identities. In the later Middle Ages there are significant differences between the mainly agrarian plains and the low mountain ranges, which were settled only in the course of the previous centuries. The opening of mountainous regions is seen as a process of colonisation beginning at the end of the $1^{\text {st }}$ millennium AD. Controlled by nobility, this was inspired by the chance to gain territory and access to different ores. However, recent studies show that the colonisation of low mountain ranges started in the early Middle Ages and was probably connected with outfield land use (Schreg 2008). Currently available archaeological data are not sufficient to identify specific houses typical for marginal landscapes, whose economy was rather based on the resources of meadows and forests.

\section{WRITTEN SOURCES}

Several written sources offer insights on early medieval rural architecture (Speckmann 2010, 133ff.). Most important are the early medieval tribal laws, such as the lex Alamannorum or the lex Baiuvariorum, dating as early as the $8^{\text {th }}$ century (Schott 2006; Dölling 1958). These do not describe the houses, but they list penalties for property damage, housebreaking, and theft. These texts mention buildings with special functions, such as granaries, stables for sheep and pigs, as well as the domus (house), sala (hall) and bath $(s t u b a)$. However, details of these structures were not mentioned. Some passages concerning doors and roofs as well as of the height of houses have been used for reconstructions. Philological critique, however, demonstrated some misinterpretations of the texts. Furthermore, it is unclear whether these legal texts reflect regional architecture. Therefore it is impossible to use these texts for a direct identification of structures in the archaeological record (Willmy 1997).

There are also some details we can learn from manorial lists of tributes. Some of them mention wood shingles as an annual tribute. Wood shingles were fixed with iron nails (MGH in folio SS. 2, 294 [Gesta abbatum Fontanellensium]). However, these seem to be restricted to western territories in modern France (Goetz 1989, 508 [Polyptichon of St. Germain-des-Près]; Schwab 1983 [rental of Prüm abbey]). Archaeological evidence in Germany dates only from the $11^{\text {th }}$ century onwards (Koch 1998), and to date is completely absent in rural contexts.

Textual information therefore is rather limited. Texts point to farmsteads with several buildings, but do not give descriptions or details that would allow us to identify regional architectural traditions. The terms used in the texts are rather of philological interest than of positive value for house reconstructions. 


\section{BUILDINGS AND INFRASTRUCTURE OF RURAL FARMS}

Archaeological excavations normally recover the overlying soil, which is most often disturbed by later ploughing. Original surfaces and floors therefore are only observed in extraordinary situations, such as in the artificial dwelling hills at the North Sea coast, known as Terp, Wierde, Warft, or Wurt. Layers of dung raised the level of the settlement and covered earlier buildings. In inland areas, sediments in some cases covered houses, but subsequent soil formation makes it difficult to identify old surfaces.

Early medieval rural architecture is in general a wooden architecture. It is important to emphasize that archaeological remains consist mainly of slightly different colours within the soil, indicating the position of posts and walls. In contrast to stone architecture, in which stone walls form a barrier for soil erosion, the archaeological record of wooden architecture is subject to complex formation processes during construction, maintenance, and decay. Wooden posts dug into the ground are subject to rotting and persist only for a few decades.

Stone architecture was not completely absent. Carolingian architecture is known from imperial palaces at Aachen and Ingelheim, as well as from churches and abbeys (Grewe 2001; Untermann 1999). In rural landscapes, however, stone architecture was restricted to churches. In Southwest Germany stone churches are very well known at least since the $7^{\text {th }}$ century (Scholkmann 2003; Krohn 2010), even in the context of rather rural settlements. In Berslingen (Northern Switzerland), for example, the church was the sole stone building within the settlement. It was a simple rectangular building of $10.6 \times 6$ $\mathrm{m}$. The walls were $55-60 \mathrm{~cm}$ in width and preserved up to a height of one meter. The interior was prepared by a screed and divided by the stone foundation of a jube (Bänteli 2000, 69-71). Stone foundations appear in farmsteads beginning in the $11^{\text {th }} / 12^{\text {th }}$ c., when settlements became more permanent (Zimmermann 1998; Schreg 2002). These architectural changes were probably interdependent with rural social hierarchies and changing agrarian practices including a reduced importance of shifting settlements and fields or gardens.

\section{MAIN HOUSE}

Farmsteads consisted in most cases of several buildings. The main building was for living, but in most cases included other functions. Because there is almost no archaeological context - despite some very special sites on the North Sea (Bantelmann 1975) - where original floors have been preserved (e.g. Schäfer 1994; Fehring 1970;

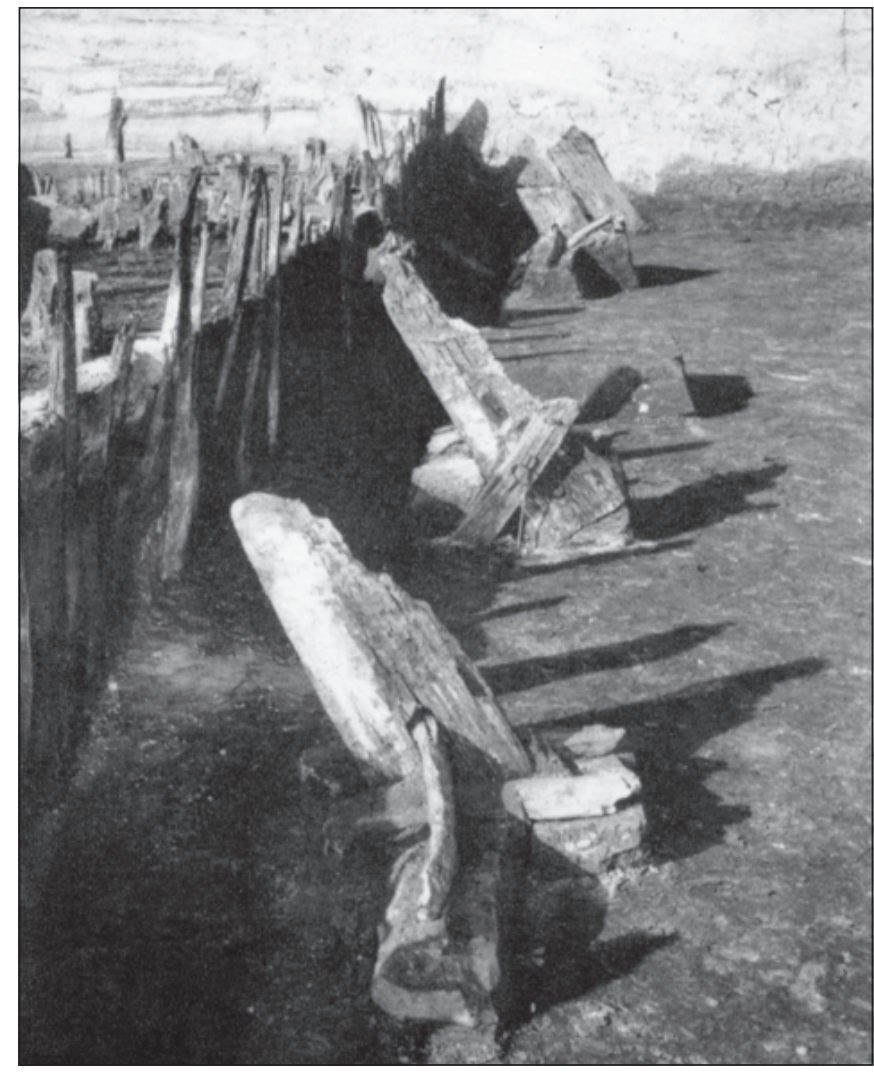

Fig. 5. Elisenhof: External slope pillars at a building (Bantelmann 1964)

Liebert 2003), analyses of activity zones and spatial behaviour within houses based on the distribution of artefacts have rarely been attempted and are not realistic in every case. Evidence for walls and roofs is sparse, and reconstructions are extremely hypothetical.

Techniques of timber joint and roof constructions are difficult to evaluate Finds of tools among grave goods, written texts, and fine woodwork represented in the cemeteries of Oberflacht and in some burials at Lauchheim show a remarkable technical level of handicraft. Mortising seems to be a common practice, as it is evident in constructions known from archaeological sites in Northern Germany (Bantelmann 1975) as well as from some singular early medieval sites in Southwest Germany (Fehring 1970; Schäfer 1994). Wells known from various settlements in Bavaria were built using log construction (Herzig et al. 2007; Meixner 2011; Winghart 1985).

Most information on building techniques comes from the North Sea region, where organic materials are preserved at some sites. For example, preservation of organic materials was excellent in the excavations at Elisenhof near Tönning, located on a marsh bank near a tidal channel (Bantelmann 1975; Szabó et al. 1985). The economy of the settlement depended on cattle grazing, but it took part 


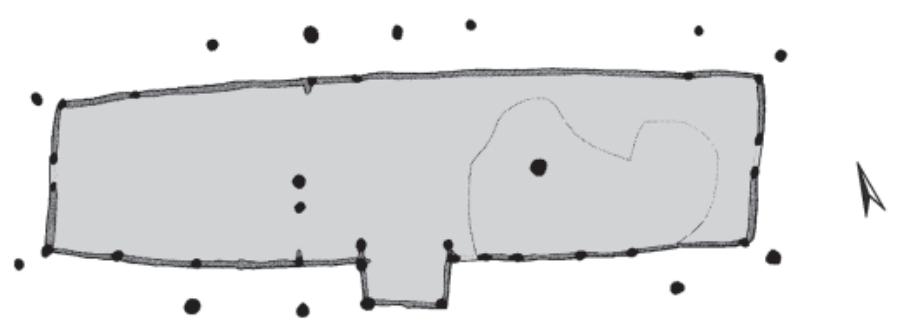

Warendorf-Velsen, Hof Dahlmann Haus 1 (7th c.)

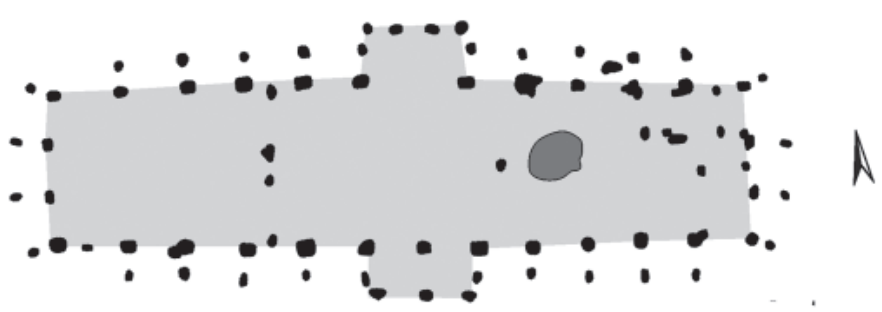

Warendorf, Neuwarendorf Westfl. Haus 7 (8th/9th c.)

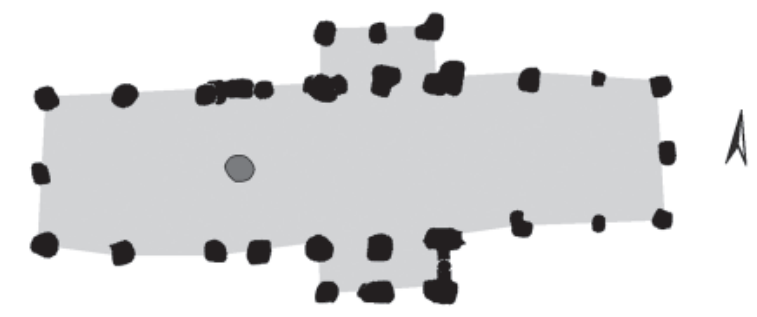

Telgte, Wöste Haus 19 (Phase 1. 9th c.)

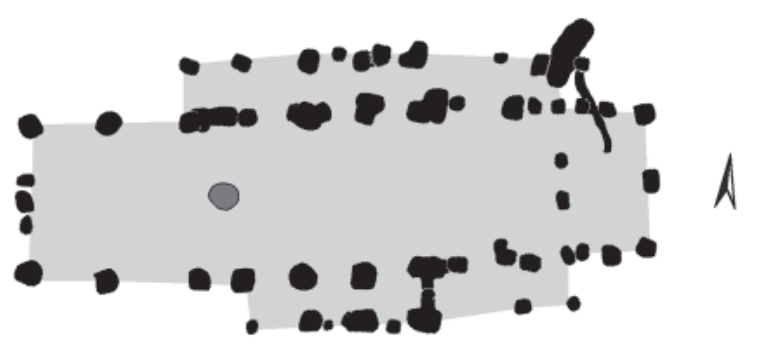

Telgte, Wöste Haus 19 (Phase 2, 9th c.)

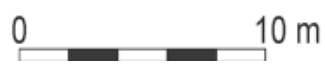

Fig. $6.7^{\text {th }}-9^{\text {th }}$ C. houses from Westphalia (Ruhmann 2006)

in the Frankish-Frisian maritime trade. There were threeaisled stable houses providing space for more than 32 cattle. In some houses the living section was constructed as a hall without internal posts. This is one of several medieval innovations which changed long-lasting building traditions of three-aisled stablehouses going back at least to the Bronze Age (Zimmermann 1988). More solid wall constructions using cleaved planks came along with a new layout of the internal framework and new roofing techniques. Oblique external posts took the pressure of a roof rafter (fig. 5). As a toppled wall at Elisenhof demonstrates, walls could be $2 \mathrm{~m}$ in height (Bantelmann 1975; Kossack et al. 1986, 183ff.), sometimes sods have been observed as isolation and stabilisation. However, there may have been regional differences. Houses at Dalem, a settlement from $7^{\text {th }}$ to $14^{\text {th }}$ c. near Flögeln, situated in the moraine 


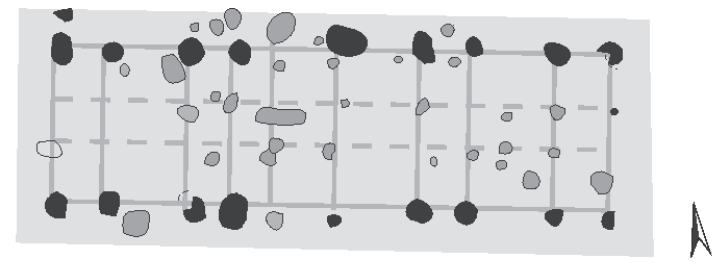

Heidenheim, Kastell

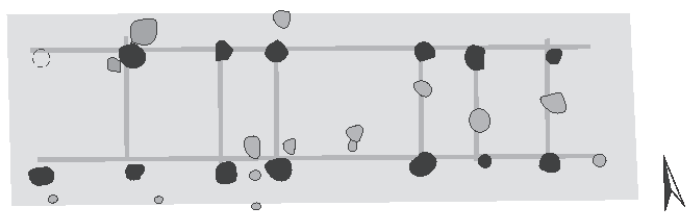

Heidenheim, Kastell

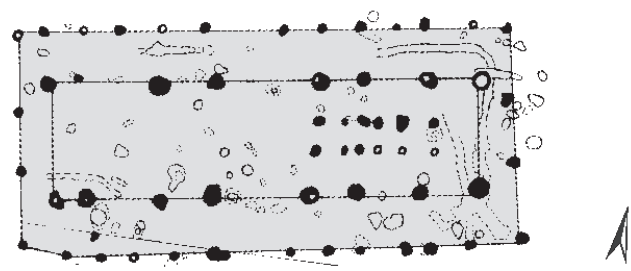

Heidenheim, Fürsamen

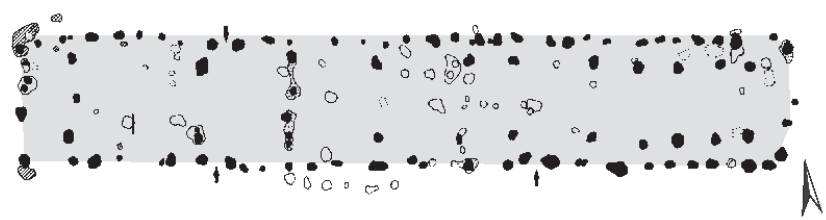

Flögeln, Eekhöltjen

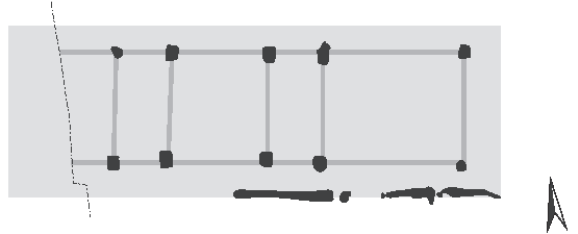

Renningen, Raite

Haus 4
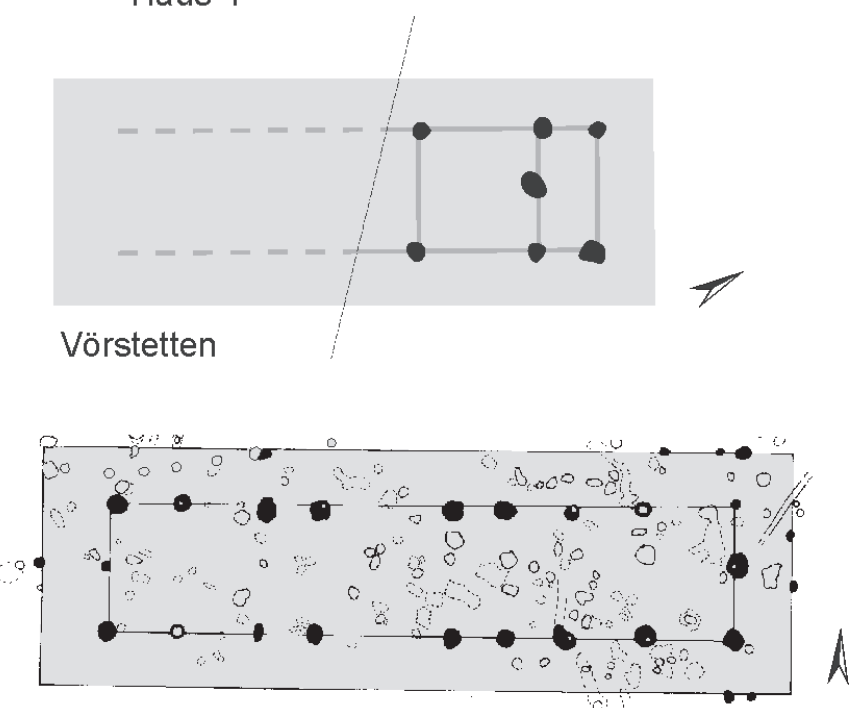

Heidenheim, Fürsamen

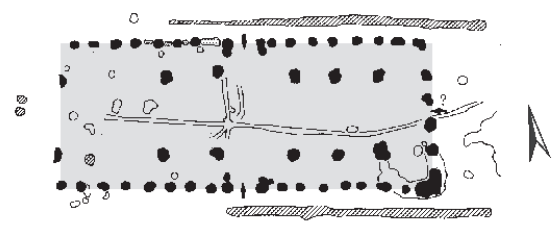

Flögeln, Eekhöltjen

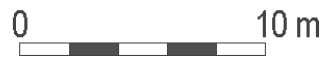

Fig. 7. Late iron Age and Migration period three-aisled houses from Southern and Northern Germany (adopted from Mc Cabe, Bücker 2000; Scholz 2001; Scholz 2005/ 2006; Schreg 2006b).

landscape, were of a different type, as they can also be found in Westphalia, further to the south. In general they also combined living rooms and stables but in the beginning they had no internal posts. Their central part however often had alcoves and a central corridor dividing the living room and the stable. In the course from the $7^{\text {th }}$ to the $9^{\text {th }}$ century there also have been some changes. External slope pillars abandoned and in the course of the time a lateral neap annex under the roof developed instead. The result was a three-aisled house, whose spatial organisation was quite similar to prehistoric buildings and the modern
«Niedersachsenhaus» (Ruhmann 1999; Speckmann 2010) but probably with different technical solutions of the roofing.

During the existence of the settlement at Warendorf from $2^{\text {nd }}$ half of the $7^{\text {th }} \mathrm{c}$. to the early $9^{\text {th }} \mathrm{c}$. the ground plan of the main houses changed (fig. 6). Whereas the main scheme of construction stayed constant, the ground plan changed from a rectangle to vessel's form. The straight walls were replaced by curved ones (Ruhmann 2006).

In general rural architecture in Southern Germany is quite different from the houses in the North. However in 


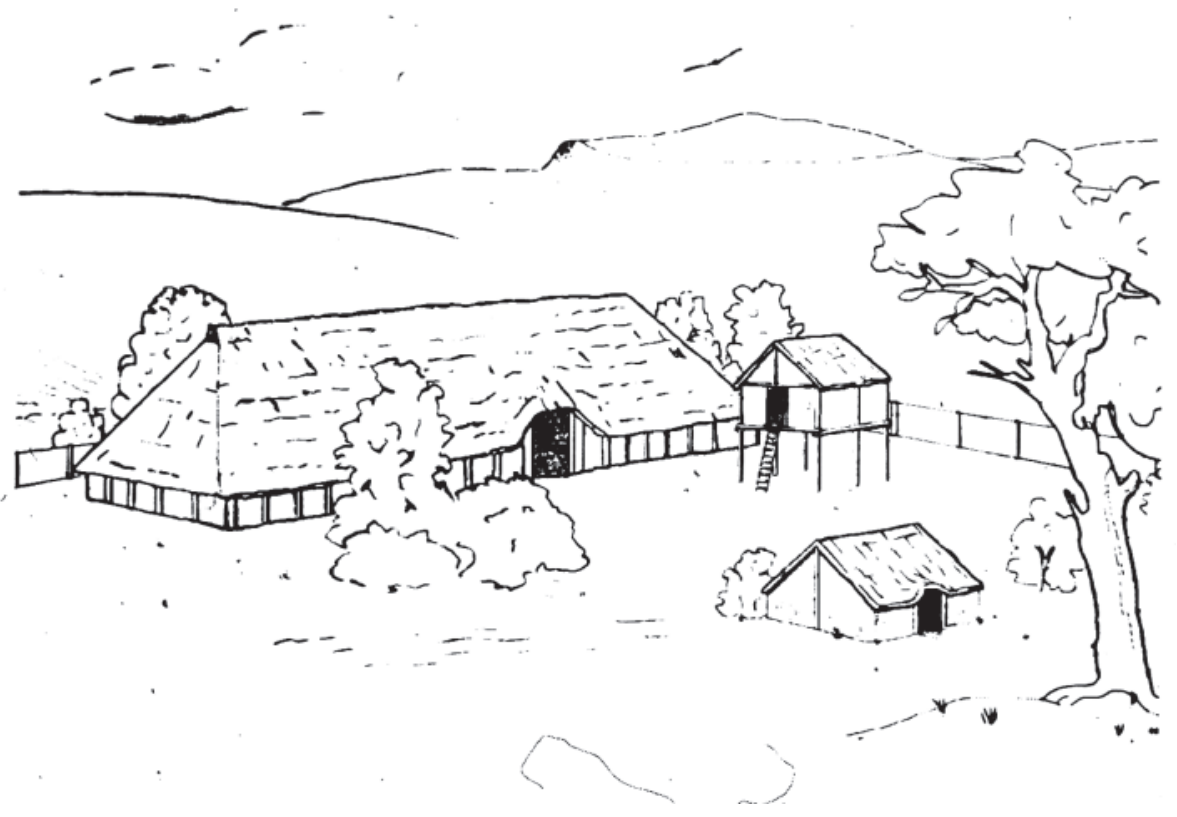

Fig. 8. Ideal reconstruction of a migration period farmstead, inspired by the archaeological record at RenningenRaite (drawing R. Schreg)

the migration period three-aisled houses were also usual in the Alamannic region in the Southwest (fig. 7). Though, the outer walls were often not visible in the archaeological record on mineral soils. At Renningen excavations within a migration period settlement (fig. 8) revealed large houses which have in preliminary reports described as one-aisled houses. Only the rectangular posts of the inner framework were deeply dug in the ground. Their arrangement in bays of alternating width as well as the sparse remain of the outer wall in Renningen clearly shows their affinities to the three-aisled houses in the North (Brabandt 1993; Schreg 2006b, 170 ff.).

Later buildings in early medieval Alamannia show a broad variety of ground plans. Most common are houses with just two rows of posts. Examples are known from Lauchheim, Stetten, Schalkstetten and Renningen. In general we can reconstruct one-aisled houses. However, the existence of walls not visible in the archaeological record should be considered.

Furthermore there are many two-aisled houses with three rows of posts. Probably these houses represent a ridge construction. Examples can be found at Renningen and Stetten (fig. 9). At the somewhat earlier settlements of Lauchheim and Schnaitheim they seem to be absent (Stork 2010; Leinthaler 2003).

Post holes visible in the archaeological record refer to smaller dimensions of the main static posts. Whereas the houses at Warendorf measure appr. 14 - 29 by $4.5-7 \mathrm{~m}$ (Winkelmann 1954), the houses in Southern Germany are smaller. The average two-aisled houses Renningen-Neuwiesenäcker measure appr. $10 \mathrm{~m}$ by 4.4 meters and have a ratio of $2: 1$. One aisled houses from the nearby migration period settlement Renningen-Raite measure 14.4 by $6.3 \mathrm{~m}$ with a ration of 1:2.3 (Schreg 2006b).

Even if there are no traces left from roof constructions, these differences in the ground plan refer to basically distinct concepts of timbering. There are different modes of wall construction visible in the archaeological record. In most cases the walls did not left any traces in the ground and presumably they consisted of wattle and daub. Sometimes there are small narrow trenches as at some examples in Lauchheim and Schnaitheim without any deep posts. It has been suggested, that they represent bedding trenches for sill beams or a wall construction made of thick planks (Damminger 1998, 35), neglecting the problem of humidity and fast rotting. In some cases there are traces of smaller posts visible within the trench. It was only in the high Middle Ages, when wall constructions were based on narrow stone foundations to prevent the timber work from humidity (Zimmermann 1998).

At the first glance the houses in Southern Bavaria have large similarities with those of the Alamannic landscapes in Southwestern Germany. The main form of houses consists of one- or two-aisled houses, sometimes with additional side wings. They may have been an extension of the interior or open eaves. Because massive ridge posts were often not present at the narrow side, a hipped end roof construction has been suggested. Posts in the middle axis 


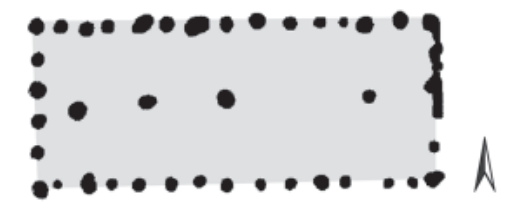

Stetten a. d. Donau

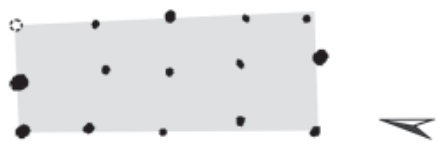

Renningen, Neuwiesenäcker, Haus 4 (11./12th c. ?)

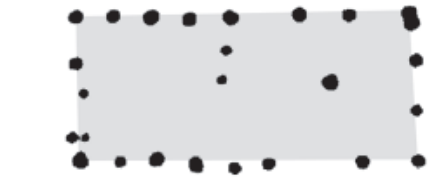

Ehingen (6th c.)

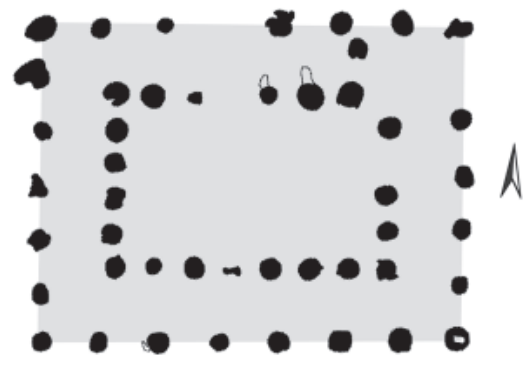

Irlbach (8th c.)

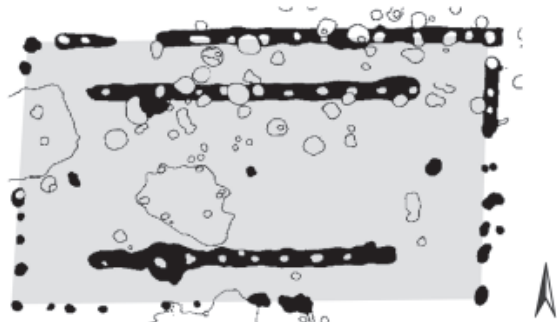

Eggingen, Lippenöschle Haus K (11th c.)

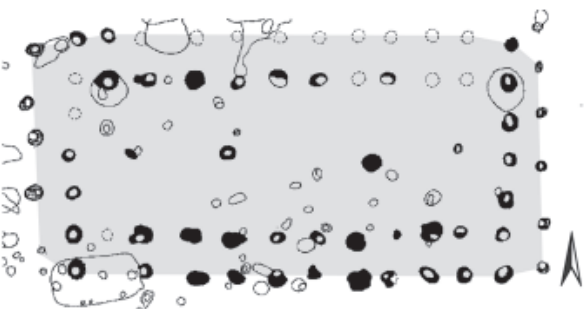

Eggingen, Lippenöschle Haus Ab (11th-14th c.)

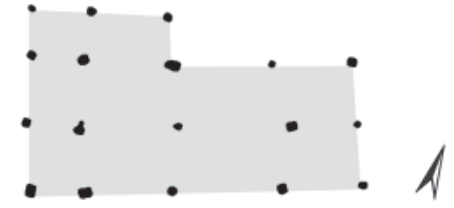

Kirchheim b. München, Haus 1970/1

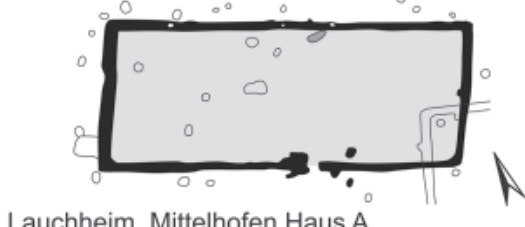

Lauchheim, Mittelhofen Haus A

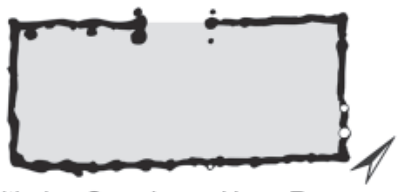

Schnaitheim, Seewiesen Haus R

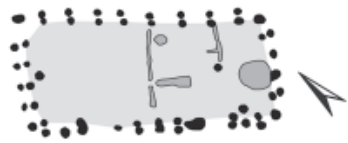

Schnaitheim, Seewiesen Haus K

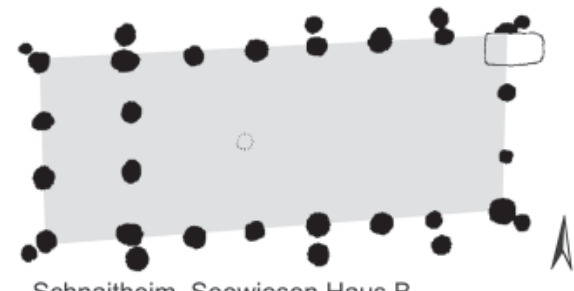

Schnaitheim, Seewiesen Haus B

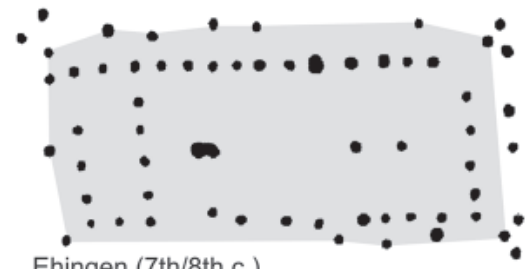

Ehingen (7th/8th c.)

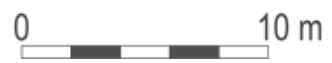

Fig. 9. Selected ground plans of main houses from Southwestern Germany (adopted from Schreg 2006b; Leinthaler 2003; Kind 1989; Bücker, Hoeper 2000; Stork 2010; Dannheimer 1973)

were often not in regular distances but they correspond with posts of the wall constructions (Geisler 1997; Geisler 1993; Geisler 1988; Platz 2008). It has therefore been suggested that the houses had rafter roofs (Geisler 1997, 467). As in the Alamannic landscapes there are some houses with a leaf-like stem, which support the protruding roof. Examples are known e.g. from Eching and Harting in
Bavaria as well as from Schnaitheim and Ehingen in Alamannia (fig. 9).

At Irlbach in Lower Bavaria a 18 by $13 \mathrm{~m}$ house consisted of two concentric rectangles of large chisseled posts (Böhm 1992) (fig. 9). In contrast to the Irlbach case we can see at similar houses at Ulm-Eggingen (fig. 9) or Lauchheim in Southwestern Germany some central posts 
marking a ridge construction. Whereas the house in Irlbach dates in the $8^{\text {th }} \mathrm{c}$., the examples from Eggingen are later.

\section{ECONOMIC BUILDINGS}

Early medieval farmsteads consisted of several buildings. In contrast to the compact farms of the late Middle Ages and early modern period, they were irregular conglomerations of several buildings. The main building included accommodation for the peasant family and livestock. There were special buildings for handicraft and storage.

A characteristic of most known early medieval rural settlements are pit houses. Most of them were around 3 to 4 meters in size and were dug into the ground up to $0.9 \mathrm{~m}$.
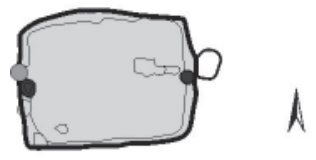

Renningen, Neuwiesenäcker Grubenhaus 12

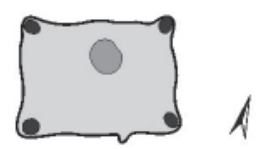

Eggingen, Lippenöschle Grubenhaus N

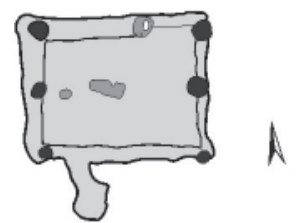

Renningen, Raite Grubenhaus 3

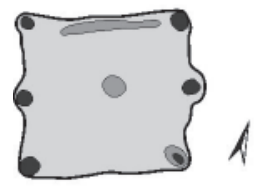

Eggingen, Lippenöschle Grubenhaus E

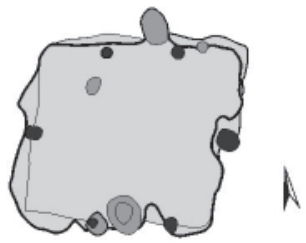

Renningen, Raite Grubenhaus 8
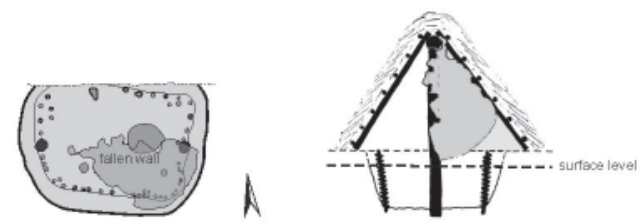

Reinach BL, Stadthof Grubenhaus S13

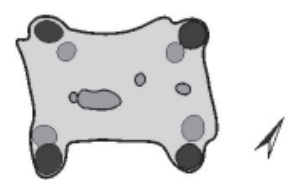

Schnaitheim, Seewiesen Grubenhaus 823

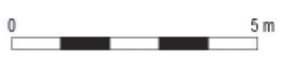

Fig. 10. Pithouses from Southwestern Germany (Schreg 2006b; Leinthaler 2003; Kind 1989; Marti 2011) 


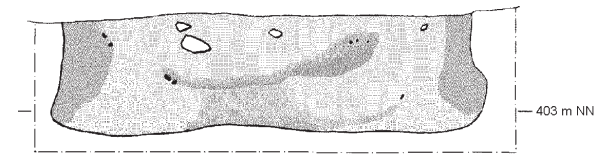

Renningen, Neuwiesenäcker Grube Bef. 3/588

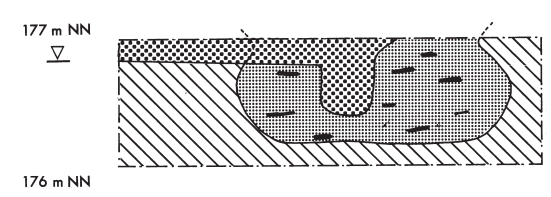

Fritzlar, Holzheim

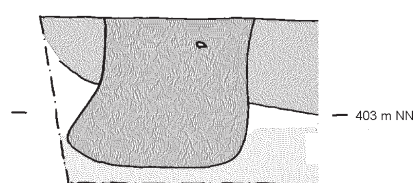

Renningen, Neuwiesenäcker Grube Bef. 3/572

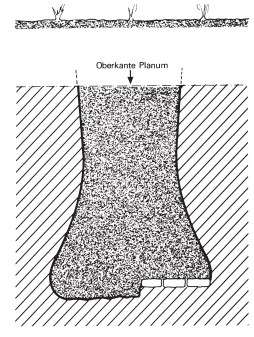

Herrenberg, Reistingen

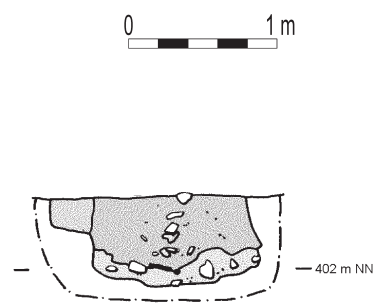

Renningen, Neuwiesenäcker Grube Bef. 3/422

Fig. 11. Storage pits (Schreg 2006; Wand 2002)

There have been different forms of constructions. Traces of postholes within the pit allow distinguishing different types by the number and position of the posts (fig. 10).

There are pit houses with 2, 4 or six posts. Six post pit houses may represent several modes of construction depending from the arrangement of the posts. Sometimes the ridge post is in one row with the post in the edges. Sometimes he is slightly moved in front of the line determined by the edges (Donat 1980, 83ff.; Donat 1991; Zimmermann 1992b; Schreg 2006b, 159-164; Marti 2011). In some six post pit houses there are no posts in the edges. They are arranged hexagonally with ridge posts and two posts on each long side (Schreg 2006b, 160ff.).

Reconstructions of early medieval pit houses agree in the idea of the pit houses as an independent building, whereas in later Middle Ages as well as in the Slavonic

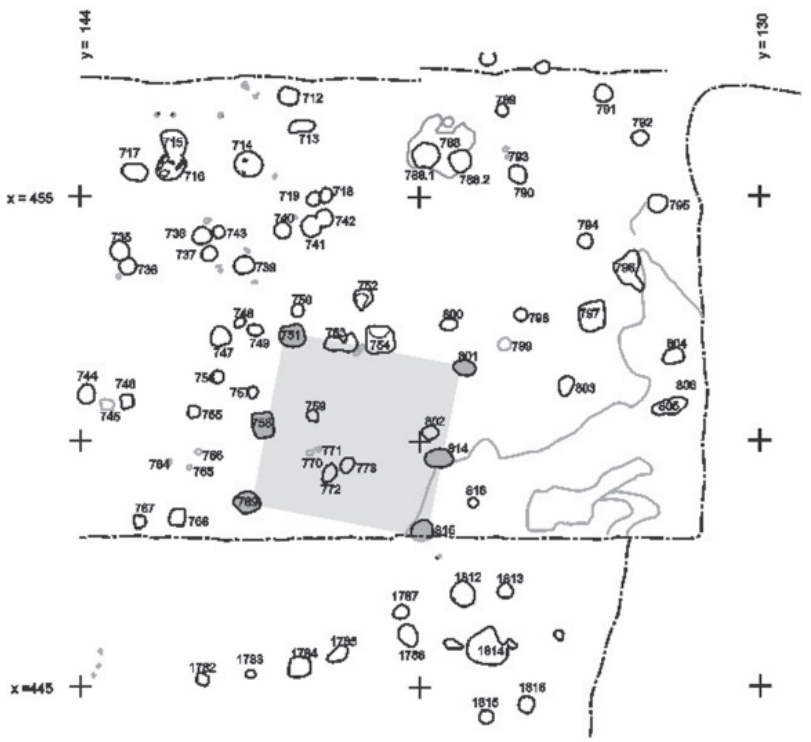

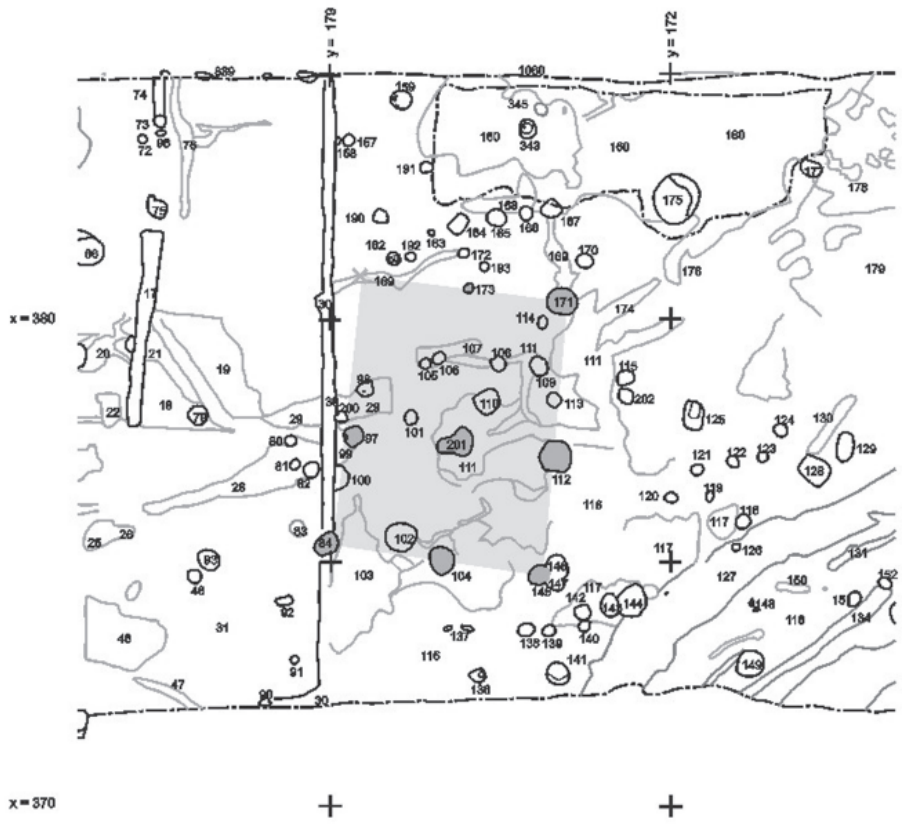

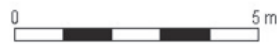


landscapes there is a discussion whether the pit houses could have been the cellars of larger, at-grade buildings which may not be present in the archaeological record (Timpel 1996). At Reinach in Northern Switzerland the entire burnt wall of the entrance flank has collapsed into the pit. The pit house is of the two-post type. Small stakes on all four flanks indicate a wattle work construction, but the whitewashed loam was set on the outer border of the pit and did not reach into the pit. The reconstructed wall indicates a precipitous roof as usual with reed cover. Obviously one side of the flank was open (Marti 2011, 12f.).

In contrast to the Slavic settlement landscapes pit houses in the west nearly never were furnished with a fire place. Instead we often find traces of weaving looms. By now there is no detailed study comparable to the analysis of post holes inside the pit houses as at Villiers-le-Sec in France (Gentili 2009). However, post holes and trenches in several pit houses indicate a similar variety of constructions of weaving looms (Zimmermann 1992b, 156ff.).

There are several ways of storage present in the archaeological records of early medieval farmsteads. They continue pre-Roman practices. At the one hand, there are storage pits (fig. 11). They were often bell-shaped. Their former opening is eroded in most cases. Therefore it is hard to determine their storage volumes. A rather well preserved pit at Herrenberg measures $1.4 \mathrm{~m}$ in depth, but others were probably shallower (Gross 1988).

On the other hand there are small buildings of four or six, sometimes of eight or nine posts at a square ground plan (fig. 12). Round storages are more common in the Northern landscapes. They were probably used to store hay for the livestock, whereas in the landscapes to the south pits and small buildings were used to retain the grain (Zimmermann 1991; Schreg 2006b, 172f.).

\section{FENCES, DITCHES AND FARMSTEAD ORGANISATION}

Only in some cases we can trace the lines of some fences. This is in a remarkable contrast to the complex systems of ditches and fences we know for example from medieval settlements in Northern France. Actually we have many examples of high medieval village fences or even ditches from eastern Germany but few examples from the west and the south. Therefore it is quite hard to fix possible traditions coming from Iron Age settlements which were in many cases fortified.

At Lauchheim there is a small ditch delimiting the settlement to the south. It has been suggested to understand this as the borderline of the village marked by a fence. In later texts the «Etter» refers to the juridical territory of the inner village with special legal conditions, but it refers also to the borderline often marked by a fence or - in later times - even by a stone wall.

Because of the rarity of fences it is quite hard to delimit the farmsteads and to determine the actual size of the farmstead (Steuer 1982, 258ff.). Furthermore houses can normally be dated just by finds from post holes. Therefore it proofs difficult to establish a chronology of the settlements. It's mainly the filling of pithouses which allows tracing the shifting locations of settlement activities. There are many examples showing, that early medieval settlements may have shifted in a small area. There is an ongoing debate about the background of this phenomenon (Schreg 2012). As the distances are rather small it is probably not a kind of shifting cultivation within a forested environment, but a long-term change of well manured settlement areas and agrarian fields or gardens. However, there is little information about the early medieval land use practices (comp. Fries 1995).

\section{CHANGES IN TIME}

Within the time period from the 5th to the 10th century there have been many changes in rural architecture in detail. The major changes in rural settlements however took place at the very beginning of this period and in the $10^{\text {th}} / 11^{\text {th }}$ century or even later. At least in the west the $5^{\text {th }}$ century seems to be a period of spatial reorganisation. This is however a conclusion mainly based on the evidence of cemeteries. The question how settlement pattern changed during the $5^{\text {th }}$ century is still under discussion. More detailed landscape studies based rather on settlement remains than on cemeteries are needed. Remarkably the three-aisled houses seem to disappear in most landscapes at around this time. They were replaced by other house types of different ground plans, but probably with a similar functionality. Maybe the same is true for pit houses with a hexagonal arrangement of posts, which also disappear in the $5^{\text {th }}$ and $6^{\text {th }}$ century. Architecture in the Merovingian and Carolingian period shows a broad regional variety and there have been some changes in time. For example, the houses in Westphalia show a development in their ground plan and construction (fig. 6), but it is hard to decide how these architectural changes were connected to changing economic requirements and changing social practices. The same is true for the development of pit houses in Southern Germany. In trend there is a development from 1) six post pit houses with posts in the corners and ridge posts directly in front of the end wall, over 2) six post pit houses with 
ridge posts integrated in the end wall, to 3) four and two post pit houses (Kind 1989, Abb. 219; Bänteli 2000, Abb. 35).

It is hard however to understand the social and economic background, as the general outline of the farmsteads stayed rather constant. Possibly there was an intensification of agrarian land use since the early Middle Ages, which lead to a reorganisation of the farmsteads. A declining importance of herding and an intensified agrarian land use should have had effects on capacities of stables and barns. Changes in storage capacities, in the number of stables as well as in the size of the living area around the fireplace are hardly to verify. There are some calculations of stable capacities within the three-aisled houses in northern Germany concerning the migration period (Schreg 2006b). However, there are few data for later centuries. Because phosphate analyses have rarely used, there are only few examples, which indicate that even the smaller houses of Merovingian and Carolingian period in Southern Germany were combined stable houses. At least in the South the number of granaries seems to be declining in later centuries. Probably other storages were used, as possibly in the upper floor. Up to the Carolingian period settlements were often characterized by parallel, often east-west orientated houses. In many cases they were arranged along a road. Later settlements show a rather unregulated arrangement of houses. In several settlements there are distinct periods of specific spatial organisation. At Berslingen for example there has been a period of rectangular arrangement of houses during the early $9^{\text {th }}$ and the $10^{\text {th }}$ century (Bänteli 2000, 77).

Fundamental changes in settlement pattern as well as in architecture date to the beginning of the second millennium, already later than the time period under consideration. In the $12^{\text {th }} / 13^{\text {th }}$ centuries, in some regions as in Bavaria maybe already in the $10^{\text {th }} / 11^{\text {th }}$ centuries there was a process of settlement concentration. Within this process of medieval village formation with its reorganisation of land use by means of an open field system, the development of village communes, and a settlement concentration close to the church and the former manorial court, there was also a change in rural architecture (Schreg, 2006b; 2009). Pit houses disappeared. Post constructions were displaced by timber frames, often with stone foundation. Furthermore, since the $12^{\text {th }}$ century the open fireplace was replaced by tile stove and separate kitchen (Schreg 2002). These houses were much more long-lasting than the earlier ones. Recent research discovered quite a number of still standing late medieval houses (Bedal 1987; 1993).

\section{OPEN QUESTIONS AND TRENDS OF RECENT RESEARCH}

There are still many open questions in building techniques and on the construction of the houses. Currently there is an increasing number of 1:1 reconstructions. At Oerlinghausen there have been reconstructions of the Warendorf houses already since the 1980s. Recently a three-aisled house has been reconstructed at Vörstetten (Bücker 2007). Near the abbey of Lorch a Carolingian farmstead will be built within the next years. However, there is little effort to deal with the experiences gained from their construction and maintenance after some first reviews in the 1990s (Andraschko 1995, Schmidt 2000, 31-43; more general see: Ahrens 1990, 132ff.).

By now, the interest of German social archaeology in settlements and architecture was foremost lead by the reconstruction of social hierarchies. The identification of curtes mentioned in texts as well as the characterisation of manor sites ("Herrenhöfe») has been in the focus for a very long time (Hinz 1967; Grote 2003; Fries-Knoblach 2009; Steuer 2010). In order to understand local society however it is necessary to look beyond differences in size and function of houses and farmsteads.

Questions of the spatial organisation of living and working within the houses are a quite new field in German early medieval archaeology. The main problem is the lack of the original floors. Using phosphate analysis it has been possible to detect different activity zones within the houses and in their close surrounding (Zimmermann 2001; Bauer et al. 1993; Schreg, Behrendt 2011). The most important result is the existence of stables also within one-aisled houses in Southern Germany. Furthermore it has been possible to detect activity zones at the fire places as well as an entrance hall with an increased input of phosphate. In many cases there has been a strip of high phosphates at the southwest corner of the house which may be related to waste management (Schreg, Behrendt 2011).

Differences of dimensions of the main houses are most likely due to different economic backgrounds. Probably the importance of livestock was higher in the Northern landscapes and therefore stables within the houses were bigger and the need to store hay was higher. Future research however needs to identify local traditions of building techniques and spatial organisation at a more regional level.

Learning more about daily practices within the houses could be an important aspect not only for economic questions, but also for social and environmental archaeology. In this context the potential of phosphate analysis has 
not yet been used to its full extent. In cases a floor has been preserved micro-analysis of soils could be a possibility to understand activities within the houses.

Another interesting aspect of future research on early medieval villages and architecture comes from environmental archaeology. Understanding settlements as local human ecosystems provides a perspective which allows us to reflect on changes of rural agrarian economy, landscapes and local societies. The village ecosystem comprises the totality of the settlement, its inhabitants, its surrounding landscape and their mutual activities as a dynamic and organic whole. The function of a village ecosystem mainly depends on the major bio-productive systems such as agricultural lands, grasslands, forest and wetland. Central aspects of the village ecosystem are the energy basis, mainly determined by climatic factors, the extent and nature of the available land as well as the labour reserve. Technological skills, subsistence strategies, land tenure, social structures, reproduction, and power relations, as well as social values and world-view are crucial for the specific layout of the village ecosystem. Within the village ecosystem several elements are in mutual dependency. For example, in most European agrarian village ecosystems, cattle were required for manuring fields to preserve their fertility. As cattle herding produces lower yields per hectare than arable production, this may place stress on agrarian societies (Schreg 2011).

Rural houses provide important information on these village ecosystems as they give some ideas about the living conditions and size of families and some indication of the livestock. These data are incomplete and need to be seen in the wider context of a landscape archaeology using bioand geoarchaeological data and looking for the land use practices.

Taking the village as an ecosystem changes in rural architecture and the genesis of villages can be seen in a wider context: Before the $11^{\text {th }}$ century settlements were shifting within the fields, afterwards they became at a constant place and stone architecture gained on importance. Internal organisation changed. Probably many types of houses known from modern periods developed at that time, transforming the traditions which we have sketched in this article.

\section{Bibliography}

Ahrens, Claus (1990): Wiederaufgebaute Vorzeit. Archäologische Freilichtmuseen in Europa. Neumünster: Wachholtz.

Andraschko, Frank M. (1995): Studien zur funktionalen Deutung archäologischer Siedlungsbefunde in Rekonstruktion und Experiment. Duderstadt (Hamb. Beitr. Arch. Werkstattreihe, 1)
Bänteli, Kurt (2000): Berslingen - verschwunden und wiederentdeckt: Braune Flecken als letzte Zeugen. In Kurt Bänteli, Markus Höneisen, Kurt Zubler (Eds.): Berslingen - ein verschwundenes Dorf bei Schaffhausen. Mittelalterliche Besiedlung und Eisenverhüttung im Durachtal. Schaffhausen: Baudepartement des Kantons Schaffhausen Kantonsarchäologie (Schaffhauser Archäologie, 3), pp. 53-82.

Bantelmann, Albert (1964): Vorbericht über die Untersuchung auf der Warft Elisenhof bei Tönning. In Germania 42, pp. 227-239.

Bantelmann, Albert (1975): Elisenhof 1: Die frühgeschichtliche Marschensiedlung beim Elisenhof in Eiderstedt. Landschaftsgeschichte und Baubefunde. Bern, Frankfurt/M.: Lang (Stud. Küstenarch. Schleswig-Holstein A, 1).

Bauer, Sibylle; Küster, Hansjörg; Weski, Timm (1993): Zum täglichen Leben in der Römer- und merowingerzeitlichen Siedlung von Eching. Ergebnisse der Phosphatanalyse, Dendroarchäologie und Vegetationsgeschichte. In Arch. Korrbl. 23, pp. 111-126.

Bedal, Konrad (1987): Ein Bauernhaus aus dem Mittelalter. Bad Windsheim (Schr. u. Kat. Fränk. Freilandmus. Bad Windsheim, 9).

Bedal, Konrad (1993): Historische Hausforschung. Bad Windsheim (Quellen u. Mat. Hausforsch. Bayern, 6).

Behn, Friedrich (1957): Die Entstehung des deutschen Bauernhauses. Leipzig: Akademie-Verlag (Ber. Verh. Sächs. Akad. Wiss. Leipzig, Phil.-Hist. Kl., 103/ 3).

Bernhard, Helmut (1982): Die frühmittelalterliche Siedlung Speyer 'Vogelgesang'. In Offa 39, S. 217-233.

Biermann, Felix (2000): Slawische Besiedlung zwischen Elbe, Neiße und Lubsza. Archäologische Studien zum Siedlungswesen und zur Sachkultur des frühen und hohen Mittelalters. Bonn: Habelt (Univforsch. Prähist. Arch., 65).

Böhm, Karl (1992): „Elirespach» wiederentdeckt - ein bajuwarischer Haustyp aus Irlbach, Landkreis Straubing-Bogen, Niederbayern. In Arch. Jahr Bayern, pp. 138-140.

Brabandt, Johanna (1993): Hausbefunde der römischen Kaiserzeit im freien Germanien. Ein Forschungsstand. Halle (Veröff. Landesamt arch. Denkmalpfl. Sachsen-Anhalt, 46).

Brather, Sebastian (2001): Archäologie der westlichen Slawen. Siedlung, Wirtschaft und Gesellschaft im früh- und hochmittelalterlichen Ostmitteleuropa. Berlin: Walter de Gruyter (RGA Ergbd., 30).

Bücker, Christel (2007): Rekonstruktion der Vergangenheit - der Alamannenhof in Vörstetten (Breisgau). In Arch. Nachr. Baden 74/75, pp. 62-64.

Bücker, Christel; Hoeper, Michael (2000): First aspects of social hierarchy of settlements in Merovingian southwest Germany. In Charlotte Fabech, Jytte Ringtved (Eds.): Settlement and landscape. Proceedings of a conference in Århus, Denmark. Aarhus: Aarhus University Press, pp. 441-454.

Christlein, Rainer (1980): Kirchheim bei München, Oberbayern: Das Dorf des frühen Mittelalters. In Arch. Jahr Bayern, pp. 162-163.

Damminger, Folke (1998): Dwellings, Settlements and Settlement Patterns in Merovingian Southwest Germany and Adjacent Areas. In Ian Wood (Ed.): Franks and Alamanns in the Merovingian Period. An ethnographic perspective. Woodbridge (Studies in Historical Archaeoethnology), pp. 33-106.

Dannheimer, Hermann (1973): Die frühmittelalterliche Siedlung bei Kirchheim (Ldkr. München, Oberbayern). Vorbericht über die Untersuchung im Jahre 1970. In Germania 51, pp. 152-169.

Dannheimer, Hermann (1974): Aus der Siedlungsarchäologie des frühen Mittelalters in Bayern. In Georg Kossack, Günter Ulbert (Eds.): Studien zur vorund frühgeschichtlichen Archäologie. Festschrift für Joachim Werner z. 65. Geburtstag, vol. 2. München: C.H. Beck (Münchner Beitr. Vor- u. Frühgesch., Ergänzungsband 1), pp. 629-657.

Dölling, Hildegard (1958): Haus und Hof in westgermanischen Volksrechten. Münster (Veröff. Altertumskomm. Provinzialinst. westf. Landeskunde, 2).

Donat, Peter (1977): Stallgröße und Viehbesitz nach Befunden germanischer Wohnstallhäuser. In Joachim Herrmann (Ed.): Archäologie als Geschichtswissenschaft. Berlin (Schriften zur Ur- und Frühgeschichte), pp. 251-263.

Donat, Peter (1980): Haus, Hof und Dorf in Mitteleuropa vom 7. bis 12 . Jahrhundert. Archäologische Beiträge zur Entwicklung und Struktur der bäuerlichen Siedlung. Berlin: Akademie-Verlag (Schriften zur Ur- und Frühgeschichte, 33).

Donat, Peter (1987): Zur Herausbildung der frühmittelalterlichen Gehöftformen im südlichen Nordseegebiet. In Studien Sachsenforsch. 6, pp. 23-54. 
Donat, Peter (1991): Zur Entwicklung germanischer Siedlungen östlich des Rheins bis zum Ausgang der Merowingerzeit. In Zeitschr. Arch. 25, pp. 149176.

Donat, Peter (2001): Dlhé domy vo východnej Germánii. Úvahy k jednému problému výskumu (Langhäuser im östlichen Germanien. Überlegungen zu einem Forschungsproblem). In Slovenská Arch. 49, pp. 103-119.

Fahr, Jochen; Friederich, Susanne; Kunze, Christiane; Pacak, Peter (2008): Latdorf - eine früh- bis hochmittelalterliche Siedlungskammer. In Susanne Friederich, Harald Meller (Eds.): Archäologie am Kalkteich 22 bei Latdorf. Die Chemie stimmt! Halle (Saale): Landesamt für Denkmalpflege und Archäologie Sachsen-Anhalt (Archäologie in Sachsen-Anhalt Sonderband, 9), pp. 71-92.

Fehring, Günter P. (1970): Erpfingen, Kr. Reutlingen. Südwürttemberg. Wüstung im Gewann 'Untere Wässere'. In Nachrbl. Denkmalpfl. Baden-Württemberg 13, pp. 74-75.

Fehring, Günter P. (1973): Zur archäologischen Erforschung mittelalterlicher Dorfsiedlungen in Südwestdeutschland. In Zeitschr. Agrargesch. u. Agrarsoziologie 21, pp. 1-35.

Fries, Janine Claudia (1995): Vor- und frühgeschichtliche Agrartechnik auf den Britischen Inseln und dem Kontinent. Eine vergleichende Studie. Espelkamp: VML (Internat. Arch., 26),

Fries-Knoblach, Janine Claudia (2006): Hausbau und Siedlungen der Bajuwaren bis zur Urbanisierung. In Bayer. Vorgeschbl. 71, pp. 339-430.

Fries-Knoblach, Janine Claudia (2009): Hinweise auf soziale Unterschiede in frühmittelalterlichen Siedlungen in Altbayern. In Beitr. Mittelalterarch. Österreich 25 (Lebenswelten im ländlichen Raum), pp. 11-34.

Garscha, Friedrich; Hammel, Karl; Kimmig, Wolfgang; Kraft, Georg; Schmid, Elisabeth (1948-50): Eine Dorfanlage des frühen Mittelalters bei Merdingen (Ldkr. Freiburg). In Bad. Fundber. 18, pp. 137-183.

Gebhard, Torsten (1958): Das Verhältnis der Bauernhausforschung zur hauskundlichen Arbeit der Vor- und Frühgeschichte. In Germania 36, pp. 401-409.

Geisler, Hans (1988): Haus und Siedlung. In Hermann Dannheimer, Heinz Dopsch (Eds.): Die Bajuwaren. Von Severin bis Tassilo. 488 - 788. gemeinsame Landesausstellung des Freistaates Bayern und des Landes Salzburg Rosenheim Bayern Mattsee Salzburg. München: Prähistorische Staatssamlung München, pp. 179-184

Geisler, Hans (1993): Studien zur Archäologie frühmittelalterlicher Siedlungen in Altbayern. Dissertation München. 2 volumes. Straubing: Gesellschaft für Zeitdokumente.

Geisler, Hans (1997): Haus und Hof im frühmittelalterlichen Bayern. In Heinrich Beck, Heiko Steuer (Eds.): Haus und Hof in ur- und frühgeschichtlicher Zeit. Bericht über zwei Kolloquien der Kommission für die Altertumskunde Mittel- und Nordeuropas vom 24. bis 26. Mai 1990 und 20. bis 22. November 1991. Göttingen: Vandenhoeck \& Rupprecht (Abh. Akad. Wiss. Göttingen, Phil.-Hist. Kl. 3, 218), pp. 461-483.

Gentili, François (2009): Typologie et analyse spatiale des fonds de cabane du haut Moyen Âge en Pays de France. L'exemple de Villiers-le-Sec et des sites environnants: Baillet-en-France, Les Mesnil-Aubry, Louvres et Villier-le-Bel. In François Gentili, Amie Lefevre (Eds.): L'habitat rural du haut Moyen Âge en Île-de-France. Guiry-en-Vexin (Suppl. au Bulletin archéologique du Vexin français, 2), pp. 31-59.

Gilles, Karl-Josef (1994): Die spätrömische Weinkelter in Erden. In Funde u. Ausgr. Bez. Trier 26, pp. 33-41.

Goetz, Hans-Werner (1989): Bäuerliche Arbeit und regionale Gewohnheit im Pariser Raum im frühen 9. Jahrhundert. Beobachtungen zur Grundherrschaft von Saint-Germain-des-Prés. In Hartmut Atsma (Ed.): La Neustrie. les pays au nord de la Loire de 650 à 850, vol. 1. Sigmaringen (Beih. Francia, 16), pp. 508-522.

Gramsch, Alexander (2003): Landschaftsarchäologie - ein fachgeschichtlicher Überblick und ein theoretisches Konzept. In Jürgen Kunow, Johannes Müller (Eds.): Landschaftsarchäologie und Geographische Informationssysteme. Archäoprognose Brandenburg I. Symposium Landschaftsarchäologie und Geographische Informationssysteme - Prognosekarten, Besiedlungsdynamik und Prähistorische Raumordnungen: vom 15. bis 19. Oktober 2001 in Wünsdorf, vol. 8. Wünsdorf (Forsch. Arch. Brandenburg, 8), pp. 35-54.
Grewe, Holger (2001): Die Ausgrabungen in der Königspfalz zu Ingelheim am Rhein. In Lutz Fenske, Jörg Jarnut, Matthias Wemhoff (Eds.): Deutsche Königspfalzen. Beiträge zu ihrer historischen und archäologischen Erforschung. Neue Forschungen zu Paderborn und anderen Pfalzen der Karolingerzeit. Göttingen: Vandenhoeck \& Ruprecht (Veröff. MPI Gesch., 11/5), pp. 155-174.

Grimm, Paul (1939): Hohenrode, eine mittelalterliche Siedlung im Südharz. Halle (Veröff. Landesanst. Volksheitskde. Halle, 11).

Gross, Uwe (1988): Neue Beobachtungen im Bereich der Wüstung Reistingen, Stadt Herrenberg, Kreis Böblingen. In Arch. Ausgr. Baden-Württemberg, pp. 265-268.

Grote, Klaus (2003): Bernshausen. Archäologie und Geschichte eines mittelalterlichen Zentralortes am Seeburger See. Bonn: Habelt (Zeitschrift für Archäologie des Mittelalters, Beiheft, 16).

Haarnagel, Werner (1979): Die Grabung Feddersen Wierde. Methode, Hausbau, Siedlungs- und Wirtschaftsform, sowie Sozialstruktur. Wiesbaden: Steiner, Franz (Feddersen Wierde, 2).

Herrmann, Joachim (1973): Die germanischen und slawischen Siedlungen und das mittelalterliche Dorf von Tornow, Kr. Calau. Berlin (26).

Herrmann, Joachim (Ed.) (1985): Die Slawen in Deutschland. Geschichte und Kultur der slawischen Stämme westlich von Oder und Neiße vom 6. bis 12. Jahrhundert. Ein Handbuch. Neubearbeitung. Berlin: Akademie-Verlag (Veröff. Zentralinst. Alte Gesch. u. Arch. Akad. Wiss. DDR, 14).

Herzig, Franz; Losert, Hans; Szameit, Erik (2007): Ein dendrodatierter Brunnen des 8. Jahrhunderts in Dietstätt: Gemeinde Schwarzach b. Nabburg, Landkreis Schwandorf, Oberpfalz. In Arch. Jahr Bayern, pp. 106-108.

Heyne, Moriz (1899): Das deutsche Wohnungswesen von den ältesten geschichtlichen Zeiten bis zum 16. Jahrhundert. Leipzig: Hirzel (Fünf Bücher deutscher Hausaltertümer, 1).

Hinz, Hermann (1967): Die Stellung der Curtes innerhalb des karolingischen Wehrbaus. In Germania 45, pp. 130-142.

Jankuhn, Herbert (1973): Umrisse einer Archäologie des Mittelalters. In Zeitschr. Arch. Mittelalter 1, pp. 9-19.

Jankuhn, Herbert (1977): Einführung in die Siedlungsarchäologie. Berlin: Walter de Gruyter.

Janssen, Walter (1968): Mittelalterliche Dorfsiedlungen als archäologisches Problem. In Frühmittelalterl. Stud. 2, pp. 305-367.

Kind, Claus-Joachim (Ed.) (1989): Ulm-Eggingen. Die Ausgrabungen 1982 bis 1985 in der bandkeramischen Siedlung und der mittelalterlichen Wüstung. With assistance of Georg Dombek, Uwe Gross. Landesdenkmalamt BadenWürttemberg. Stuttgart: Theiss (Forsch. u. Ber. Vor- u. Frühgesch. BadenWürttemberg, 34).

Koch, Robert (1998): Eiserne Schindnägel aus archäologischen Fundkomplexen als baugeschichtliches Indiz. In Konrad Bedal, Sabine Fechter, Hermann Heidrich (Eds.): Haus und Kultur im Spätmittelalter. Berichte der Tagung «Ländliche Volkskultur im Spätmittelalter in Neuer Sicht» des Fränkischen Freilandmuseums vom 24. bis 26. April 1996. Quellen u. Mat. Hausforsch. Bayern. Bad Windsheim: Fränkisches Freilandmuseum (Schr. u. Kat. Fränk. Freilandmus. Bad Windsheim, 30), pp. 41-46.

Kossack, Georg; Behre, Karl-Ernst; Schmid, Peter (Eds.) (1986): Ländliche Siedlungen. Deutsche Forschungsgemeinschaft. 1. Nachdr. der 1. Aufl. Weinheim: Acta Humaniora (Archäologische und naturwissenschaftliche Untersuchungen an ländlichen und frühstädtischen Siedlungen im deutschen Küstengebiet vom 5. Jahrhundert v. Chr. bis zum 11. Jahrhundert n. Chr, 1).

Kossinna, Gustaf (1911): Die Herkunft der Germanen. Zur Methode der Siedlungsarchäologie. Würzburg: Curt Kabitsch (Mannus-Bibliothek, 6).

Krohn, Niklot (2010): Kirchenarchäologie heute. Fragestellungen - Methoden Ergebnisse. 1. Aufl. Darmstadt: Wissenschaftliche Buchgesellschaft (Schriften des Alemannischen Instituts Freiburg).

Krüger, Bruno (Ed.) (1967): Dessau-Mosigkau. Ein frühslawischer Siedlungsplatz im mittleren Elbegebiet. Berlin: Akademie-Verlag (Schriften der Sektion für Vor- und Frühgeschichte, 22).

Kuhnen, Hans-Peter (Ed.) (1992): Gestürmt - Geräumt - Vergessen? Der Limesfall und das Ende der Römerherrschaft in Südwestdeutschland. Stuttgart (WLM Stuttgart. Führer Arch. Samml. Führer u. Bestandskat., 2).

Leinthaler, Beate (2003): Eine ländliche Siedlung des frühen Mittelalters bei 
Schnaitheim, Lkr. Heidenheim. Stuttgart: Theiss (Materialh. Arch. BadenWürttemberg, 70).

Liebert, Thomas (2003): Neue Feuchtbodenbefunde im Schwarzachtal bei Großhöbing, Lkr. Roth - Ein Vorbericht. In Beitr. Arch. Mittelfranken 7, pp. $67-75$.

Marti, Reto (2011): Siedlungsbefunde im ländlichen Raum der Nordwestschweiz. In: Siedlungsbefunde und Fundkomplexe der Zeit zwischen 800 und 1350. Akten des Kolloquiums zur Mittelalterarchäologie in der Schweiz, Frauenfeld, 28. - 29.10.2010. Basel: Archäologie Schweiz, pp. 11-23.

Mc Cabe, Coinneach; Bücker, Christel (2000): Kugelbechergruppen und frühe Alamannen in Vörstetten, Kreis Emmendingen. In Arch. Ausgr. BadenWürttemberg, pp. 132-137.

Meixner, Gerhard (2011): Überraschung am Ortsrand: Bestattungsplatz und Ansiedlung mit hölzernen Brunnen des ausgehenden frühen und beginnenden Hohen Mittelalters bei Pankofen, Stadt Plattling, Lkr. Deggendorf ein Vorbericht. In Vortr. Niederbay. Archäologentag 29, pp. 139-186.

N.N. (1914/16): Kanzach In Fundber. Schwaben 22/24, p. 41.

Ohlenroth, L. (1937): Zum Hausbau des frühen Mittelalters in Süddeutschland. In Mannus 29, pp. 535-544.

Paret, Oscar (1937): Die frühschwäbischen Gräberfelder von Gross-Stuttgart und ihre Zeit. Stuttgart: Krais (Veröffentlichungen des Archivs der Stadt Stuttgart, 2).

Phleps, Hermann (1951): Deutsche Fachwerkbauten. Königstein: Langewiesche (Die blauen Bücher).

Platz, Thomas (2008): Archäologische Befunde zum frühmittelalterlichen Hausbau in Süddeutschland. In Beitr. Arch. Mittelfranken 8, pp. 191-208.

Reuter, Marcus (2003): Die römisch-frühvölkerwanderungszeitliche Siedlung von Wurmlingen, Kreis Tuttlingen. Stuttgart (Materialh. Arch. BadenWürttemberg, 71).

Ruhmann, Christiane (1999): Frühmittelalterliche Siedlungen im Münsterland. In Christoph Stiegemann, Mathias Wemhoff (Eds.): 799 - Kunst und Kultur der Karolingerzeit. Karl der Große und Papst Leo III in Paderborn. Mainz: Philipp von Zabern (3), pp. 284-290.

Ruhmann, Christiane (2006): Die Hünenburg bei Stadtlohn, Kreis Borken. Münster Westf:: Altertumskommission für Westfalen (Frühe Burgen in Westfalen, 23).

Sage, Walter (1965): Frühmittelalterlicher Holzbau. In Wolfgang Braunfels, H. Schnitzler (Eds.): Karl der Grosse. Lebenswerk und Nachleben. III. Karolingische Kunst. 1. Aufl. Düsseldorf: Schwann, pp. 573-590.

Sage, Walter (1969): Die fränkische Siedlung bei Gladbach, Kreis Neuwied. Düsseldorf (Kl. Museumsh. Rhein. Landesmus. Bonn, 7).

Sage, Walter (1983): Hausforschung und Mittelalterarchäologie. In Jahrb. Hausforsch. 33 (Hausbau im Mittelalter I), pp. 13-36.

Schäfer, Hartmut (1994): Konstruktionshölzer des frühen Mittelalters aus Winterbach, Rems-Murr-Kreis. In Arch. Ausgr. Baden-Württemberg, pp. 278-279.

Schmidt, Hartwig (2000): Archäologische Denkmäler in Deutschland - rekonstruiert und wieder aufgebaut. Stuttgart: Theiss (Archäologie in Deutschland. Sonderheft, 2000).

Scholkmann, Barbara (2003): Frühmittelalterliche Kirchen im alemannischen Raum. Verbreitung, Bauformen und Funktion. In Sönke Lorenz, Barbara Scholkmann (Eds.): Die Alemannen und das Christentum. LeinfeldenEchterdingen: DRW-Verlag (Schriften zur südwestdeutschen Landeskunde, 48), pp. $125-152$.

Scholz, Markus (2001): Reiterkasernen und alamannisches Gehöft im Alenkastell Heidenheim. In Arch. Ausgr. Baden-Württemberg, pp. 89-93.

Scholz, Markus (2005/2006): Eine römische Villa rustica und völkerwanderungszeitliche Bauernhäuser bei Heidenheim-Schnaitheim. Vorbericht der Ausgrabungen 2002 und $2004 \mathrm{im}$ Gewann «Fürsamen». In Jahrb. Heimat- $u$. Altver. Heidenheim 11, pp. 64-94.

Schott, Clausdieter (2006): Lex Alamannorum. Das Gesetz der Alemannen; Text - Übersetzung - Kommentar - Faksimile. Das Gesetz der Alemannen; Faksimile aus der Wandalgarius-Handschrift Codex Sangallensis 731. Studienausg. der 3. Aufl. Augsburg: Schwäbische Forschungsgemeinschaft (Veröffentlichungen der Schwäbischen Forschungsgemeinschaft bei der Kommission für Bayerische Landesgeschichte, 5B,3).

Schreg, Rainer (2002): Haus und Hof im Rahmen der Dorfgenese. Zum Wandel der Bauformen in Südwestdeutschland. In Jan Klápštì (Ed.): The rural house from the migration period to the oldest still standing buildings. Ruralia IV, 8. 13. September 2001, Bad Bederkesa, Lower Saxony, Germany. Conference Ruralia. Prague: Institute of Archaeology Academy of Sciences of the Czech Republic (Pam. Arch. Suppl., 15), pp. 111-122.

Schreg, Rainer (2006a): Die Archäologie des mittelalterlichen Dorfes in Süddeutschland. Probleme - Paradigmen - Desiderate. In Siedlungsforsch. 24, pp. 141-162.

Schreg, Rainer (2006b): Dorfgenese in Südwestdeutschland. Das Renninger Becken im Mittelalter. Stuttgart: Theiss (Materialh. Arch. Baden-Württemberg, 76).

Schreg, Rainer (2008): Before Colonization: Early Medieval Land-Use of Mountainous Regions in Southern and Western Germany. In Christoph Bartels, Claudia Küpper-Eichas (Eds.): Cultural Heritage and Landscapes in Europe - Landschaften - kulturelles Erbe in Europa. Internationale Konferenz 6.-10. Juni 2007 im Deutschen Bergbau-Museum Bochum. Bochum (Veröffentlichungen aus dem Deutschen Bergbau-Museum Bochum, 161), pp. 293-312.

Schreg, Rainer (2009): Siedlungen in der Peripherie des Dorfes. Ein archäologischer Forschungsbericht zur Frage der Dorfgenese in Südbayern. In Ber. Bayer. Bodendenkmalpfl. 50, pp. 293-317.

Schreg, Rainer (2011): Feeding the village - Reflections on the ecology and resilience of medieval rural economy. In Jan Klápštì (Ed.): Food in the Medieval Rural Environment - Processing, Storage, Distribution of Food. Turnhout: Brepols (Ruralia, 8), pp. 301-320.

Schreg, Rainer; Behrendt, Sonja (2011): Phosphatanalysen in einem frühmittelalterlichen Haus in Schalkstetten (Gde. Amstetten, Alb-Donau-Kreis). In Arch. Korrbl. 41 (2), pp. 263-272.

Schreg, Rainer (2012): Kontinuität und Fluktuation in früh- und hochmittelalterlichen Siedlungen Süddeutschlands. In: Carola Fey, Steffen Krieb (eds.), Adel und Bauern in der Gesellschaft des Mittelalters. Internationales Kolloquium zum 65. Geburtstag von Werner Rösener. (Studien und Texte zur Geistes- und Sozialgeschichte des Mittelalters 6), Korb: Didymos-Verlag, pp. 137-164.

Schröder, Martina (1997): Freilichtmuseen in Baden-Württemberg. Entstehung, Entwicklung, Wirkung. Tübingen (Untersuchungen des LudwigUhland-Instituts der Universität Tübingen, 86).

Schroth, Bernhard (1999): Die frühmittelalterliche Siedlung von Halle-Künsebeck. In Christoph Stiegemann, Mathias Wemhoff (Eds.): 799 - Kunst und Kultur der Karolingerzeit. Karl der Große und Papst Leo III in Paderborn. Mainz: Philipp von Zabern (3), pp. 291-294.

Schulz, Walther (1913): Das Germanische Haus in vorgeschichtlicher Zeit. Würzburg: Curt Kabitsch (Mannus-Bibliothek, 11).

Schumacher, Karl (1923): Siedlungs- und Kulturgeschichte der Rheinlande von der Urzeit bis ins Mittelalter. 3 Bde. Mainz (Handb. RGZM, 1).

Schwab, Ingo (Ed.) (1983): Das Prümer Urbar. Rheinische Urbare 5. Düsseldorf (Publikationen der Gesellschaft für Rheinische Geschichtskunde, 20).

Siegmüller, Annette (2010): Die Ausgrabungen auf der frühmittelalterlichen Wurt Hessens in Wilhelmshaven. Rahden/Westf,: VML (Studien zur Landschafts- und Siedlungsgeschichte im südlichen Nordseegebiet 1).

Speckmann, Angelika (2010): Ländlicher Hausbau in Westfalen vom 6./7. Jahrhundert bis zum 12./13. Jahrhundert. Mainz: Philipp von Zabern (Bodenaltertümer Westfalens, 49).

Spengler, Oswald (2007): Der Untergang des Abendlandes. Düsseldorf: Albatros.

Steuer, Heiko (1982): Frühgeschichtliche Sozialstrukturen in Mitteleuropa. Eine Analyse der Auswertungsmethoden des archäologischen Quellenmaterials. Göttingen: Vandenhoeck \& Rupprecht (Abh. Akad. Wiss. Göttingen, Phil.Hist. Kl. 3, 128).

Steuer, Heiko (2010): Herrensitze im merowingerzeitlichen Süddeutschland. Herrenhöfe und reich ausgestattete Gräber. In Zeitschr. Arch. Mittelalter 38, pp. 1-41.

Stork, Ingo (2010): Friedhof und Dorf - der exemplarische Fall Lauchheim. In Andreas Gut (Ed.): Die Alamannen auf der Ostalb. Frühe Siedler im Raum zwischen Lauchheim und Niederstotzingen. Begleitheft zur gleichnamigen Sonderausstellung im Alamannenmuseum Ellwangen vom 26. Juni 2010 bis 
16. Januar 2011. Esslingen: Landesamt für Denkmalpflege Baden-Württemberg (Arch. Inf. Baden-Württemberg, 60), pp. 92-105.

Szabó, Mátyás; Grenander-Nyberg, Gertrud; Myrdal, Janken (1985): Die Holzfunde aus der frühgeschichtlichen Wurt Elisenhof. Elisenhof. Die Ergebnisse der Ausgrabung der frühgeschichtlichen Marschensiedlung beim Elisenhof in Eiderstedt 1957/58 und 1961/64. In Stud. Küstenarch. SchleswigHolstein A 5, pp. 1-218.

Timpel, Wolfgang (1996): Untersuchungen zur Entwicklung und Funktion mittelalterlicher Grubenhäuser in bäuerlichen und städtischen Siedlungen Thüringens. In Hansjürgen Brachmann (Ed.): Hausbau und Raumstruktur früher Städte in Ostmitteleuropa, Prague: Institute of Archaeology Academy of Sciences of the Czech Republic, pp. 72-86 (Památky archeologické Supplementum 6).

Untermann, Matthias (1999): «opere mirabili constructa». Die Aachener 'Residenz’ Karls des Großen. In Christoph Stiegemann, Mathias Wemhoff (Eds.): 799 - Kunst und Kultur der Karolingerzeit. Karl der Große und Papst Leo III in Paderborn. Mainz: Philipp von Zabern (3), pp. 152-164.

Wagner, Karl-Heinz; Hussong, Ludwig; Mylius, H. (1938): Fränkische Siedlung bei Gladbach, Kreis Neuwied. In Germania 22, pp. 180-190.

Wahle, Ernst (1920): Die Besiedelung Südwestdeutschlands in vorrömischer Zeit nach ihren natürlichen Grundlagen. In Ber. RGK 12, pp. 1-75.

Wand, Norbert (Ed.) (2002): Holzheim bei Fritzlar. Archäologie eines mittelalterlichen Dorfes. Rahden/Westf.: VML (Kasseler Beitr. Vor- u. Frühgesch., 6).

Willmy, Andreas (1997): Trübe Quellen? Anmerkungen zu Lex Alamannorum und Lex Baiuwariorum als Hilfsmittel für die Rekonstruktion ländlicher Bauten der Alamannen und Baiuwaren. In Mamoun Fansa (Ed.): Experimentelle Archäologie. Bilanz 1997. Oldenburg (Arch. Mitt. Nordwestdeutschl. Beih., 19), pp. 7-20.

Winghart, Stefan (1985): Ein Brunnen aus der frühmittelalterlichen Siedlung von Eching. In Arch. Jahr Bayern, pp. 126-127.
Winghart, Stefan (1995): Bemerkungen zu Genese und Struktur frühmittelalterlicher Siedlungen im Münchner Raum. In Lothar Kolmer, Peter Segl (Eds.): Regensburg, Bayern und Europa. Festschr. K. Reindel zum 70. Geburtstag. Regensburg, pp. 7-47.

Winkelmann, Wilhelm (1954): Eine westfälische Siedlung des 8. Jahrhunderts bei Warendorf, Kr. Warendorf. In Germania 32, pp. 189-213.

Zimmermann, W. Haio (1988): Regelhafte Innengliederung prähistorischer Langhäuser in den Nordseeanrainerstaaten. In Germania 66, pp. 465-488.

Zimmermann, W. Haio (1991): Erntebergung in Rutenberg und Diemen aus archäologischer und volkskundlicher Sicht. In Néprajzi Èrtesitö a Néprajzi Muzeum Èvkönyve 71-73, pp. 71-104.

Zimmermann, W. Haio (1992a): Die früh- bis hochmittelalterliche Wüstung Dalem, Gem. Langen-Neuenwalde, Kr. Cuxhaven. Archäologische Untersuchungen in einem Dorf des 7.-14. Jahrhunderts. In Horst Wolfgang Böhme (Ed.): Siedlungen und Landesausbau zur Salierzeit 1. In den nördlichen Landschaften des Reiches. 2. Aufl. Sigmaringen: Thorbecke (Monogr. RGZM, 27), pp. 37-46.

Zimmermann, W. Haio (1992b): Die Siedlungen des 1. bis 6. Jahrhunderts nach Christus von Flögeln-Eekhöltjen, Niedersachsen. Die Bauformen und ihre Funktionen. Hildesheim (Probl. Küstenforsch., 19).

Zimmermann, W. Haio (1998): Pfosten, Ständer und Schwelle und der Übergang vom Pfosten- zum Ständerbau. Eine Studie zur Innovation und Beharrung im Hausbau. Zu Konstruktion und Haltbarkeit prähistorischer bis neuzeitlicher Holzbauten von den Nord- und Ostseeländern bis zu den Alpen. In Probl. Küstenforsch. 25, pp. 9-241.

Zimmermann, W. Haio (2001): Phosphatkartierungen mit großem und kleinem Probenraster in der Siedlungsarchäologie. Ein Erfahrungsbericht. In Michael Meyer (Ed.): «... trans Albim fluvium». Forschungen zur vorrömischen, kaiserzeitlichen und mittelalterlichen Archäologie. Rahden/Westf.: VML (Internat. Arch. Stud. hon., 10), pp. 69-78.

Recibido: 3 de Julio de 2012

Aceptado: 23 de octubre de 2012 